\title{
Relationships between the properties of Spitsbergen soil, number and biodiversity of rhizosphere microorganisms, and heavy metal concentration in selected plant species
}

\author{
Agnieszka Hanaka • Andrzej Plak • Piotr Zagórski • \\ Ewa Ozimek • Anna Rysiak • Malgorzata Majewska • \\ Jolanta Jaroszuk-Ścisel
}

Received: 7 July 2018 / Accepted: 31 October 2018 /Published online: 19 December 2018

(C) The Author(s) 2018

\begin{abstract}
Aims The aim of this study was to cross correlate data on physico-chemical parameters of soil with rhizosphere microorganisms and plant species in order to gain more knowledge about formation of soil and development of
\end{abstract}

Responsible Editor: Antony Van der Ent.

Electronic supplementary material The online version of this article (https://doi.org/10.1007/s11104-018-3871-7) contains supplementary material, which is available to authorized users.

A. Hanaka $(\bowtie)$

Faculty of Biology and Biotechnology, Department of Plant Physiology, Maria Curie-Skłodowska University, Akademicka St. 19, 20-033 Lublin, Poland

e-mail: agnieszka.hanaka@umcs.pl

A. Plak

Faculty of Earth Sciences and Spatial Management, Department of Geology and Soil Science, Maria Curie-Skłodowska University, Kraśnicka Ave. 2cd, 20-718 Lublin, Poland

\section{P. Zagórski}

Faculty of Earth Sciences and Spatial Management, Department of Geomorphology and Paleogeography, Maria Curie-Skłodowska University, Kraśnicka Ave. 2cd, 20-718 Lublin, Poland

E. Ozimek · M. Majewska · J. Jaroszuk-Ściseł Faculty of Biology and Biotechnology, Department of Environmental Microbiology, Maria Curie-Skłodowska University, Akademicka St. 19, 20-033 Lublin, Poland

A. Rysiak

Faculty of Biology and Biotechnology, Department of Ecology, Maria Curie-Skłodowska University, Akademicka St. 19,

20-033 Lublin, Poland plants in the face of the changing climate on Spitsbergen and relations between them.

Methods We investigated physico-chemical parameters of soil samples and the number and biodiversity of microorganisms, bacteria (oligotrophic and copiotrophic), and fungi. Moreover, heavy metal concentrations in 6 species of vascular plants collected in different areas were analysed.

Results The soil samples varied considerably in $\mathrm{pH}-$ from acid to alkaline, texture - from sand to loamy sand, and $\mathrm{C}: \mathrm{N}$ ratio - from very low to high. In the soils, only partial $\mathrm{Cd}$ elevation expressed as the geoaccumulation index $\left(\mathrm{I}_{\text {geo }}\right)$ and the enrichment factor $(\mathrm{EF})$ was detected. In the plants, the most significantly elevated concentrations of heavy metals expressed as $\mathrm{I}_{\mathrm{geo}}$ and $\mathrm{EF}$ as well as the biological accumulation factor, bioconcentration factor, and translocation factor were detected in Salix polaris, Dryas octopetala, and Draba corymbosa. The high number of bacteria corresponded with an increase in the ecophysiological diversity index and the low colony development index, whereas a reverse relationship was found for fungi.

Conclusions There was no significant impact of the geochemical properties on the total content of heavy metals in soil. The similar position of $\mathrm{Cd}$ and $\mathrm{Pb}$ in the order of heavy metal accumulation in the soil and plants was confirmed. TF showed that mainly these two metals were transported efficiently from roots to shoots. In the plants, the metals were distributed depending on the life form and their higher levels were detected in the woody perennials, e.g. S. polaris, D. octopetala, D. corymbosa, than in the herbaceous perennials. Very high numbers of 
culturable microorganisms were determined, regardless of the soil properties and plant species, which indicated that they were involved in the transformation of compounds containing $\mathrm{C}, \mathrm{N}$, and $\mathrm{P}$ and in the availability of heavy metals. The microorganisms and plants colonizing Spitsbergen soils showed great plasticity and adaptability to low temperatures and elevated $\mathrm{Cd}$ content.

Keywords Arctic · Heavy metals · Geomorphology · Bacteria $\cdot$ Spitsbergen soil $\cdot$ Vascular plants

\section{Introduction}

Arctic ecosystems are abundant in microorganisms that intensely mineralize carbon and nitrogen compounds and convert them into greenhouse gases; therefore, they might be implicated in the global climate changes (Nikrad et al. 2016). Given the ongoing climate changes leading to thawing permafrost ground, soils should receive increasing interest (Halbach et al. 2017). The physico-chemical properties (e.g. $\mathrm{pH}$, texture, organic matter, and metal content) of the soils of the Arctic vary considerably (Nikitina et al. 2015), but the Arctic and Antarctic permafrost harbours ca. $25 \%$ of the world's total soil organic material (Nikrad et al. 2016). The knowledge of the microbial and plant community structures and functions in the Arctic habitats is still insufficient. Although most of the Earth's biosphere is characterized by low temperatures $\left(<5{ }^{\circ} \mathrm{C}\right)$, coldadapted microorganisms and plants are widespread (Nikrad et al. 2016).

The area of Spitsbergen is covered by different formations, glaciers, and a few types of initial (immature) and weakly developed soils (Melke and Uziak 2006). The most important soil-forming process in permafrost areas is cryoturbation (Szymański et al. 2015). The upper parts of the soil profile are characterized by the highest content of organic carbon and nitrogen in the soil, and the texture, mineral composition, and $\mathrm{pH}$ seem to be its most important physico-chemical parameters (Szymański et al. 2016).

Svalbard is located in the subpolar climate zone, but its different parts vary considerably. The W and SW parts of the archipelago are influenced by mild polarair masses and the $\mathrm{E}$ and $\mathrm{N}$ parts are under the direct influence of Arctic masses. The interior of the $\mathrm{W}$ part has a more continental climate and is therefore warmer. The interior fjord areas and valleys (e.g.
Recherchefjorden), sheltered by the mountains, exhibit smaller temperature differences than the coast, reaching temperatures that are approx. $2{ }^{\circ} \mathrm{C}$ lower in summer and $3{ }^{\circ} \mathrm{C}$ higher in winter.

The plant distribution in the Arctic region is affected by the harsh environment, such as low nutrient availability, low temperature, and a short growing season (ca. 4 months). These conditions generally result in speciespoor communities (with low diversity) in Arctic vegetation zones compared to other similar climate regions (Kleiden and Mooney 2000). Furthermore, the relatively poor flora reflects the spatial isolation of the area from the European continent. Svalbard is classified as a physiognomic category of a sedge/grass moss wetland (Walker et al. 2006). Its flora covers approx. 10\% of the Spitsbergen area (Borysiak and Ratyńska 2004).

According to the data provided by the Norwegian Polar Institute (www.environment.no), there are 173 species of vascular plants, 373 mosses, and 597 lichens. Other sources (Nilsen et al. 1999) mention 191 taxa of vascular plants. The most numerous genera are Carex (13), Saxifraga (13), and Draba (12). On the Svalbard Archipelago, there are two regions of middle and high tundra vegetation. The criteria for distinguishing the regions include geology, local climate, persistence of snow cover, soil thawing depth, ground drainage, soil eutrophication, and vegetation grazing by reindeers, geese, and other birds. The area occupied by plants forms two zones - Cassiope tetragona occupies the central part of Spitsbergen and Dryas octopetala occurs along the western and northern coast of the island. The Dryas octopetala zone is one of the warmest regions of the island and is associated with larger groups of dry ridges, which are rich in calcium. Communities with Saxifraga oppositifolia and Salix polaris have developed in this zone (Borysiak and Ratyńska 2004). Most of the plants and soil investigated in this study were collected in this vegetation zone.

Although there are only a few sources of local pollution on Svalbard (e.g. coal mining, power plant, airport, and local traffic), heavy metals emitted at distant sites (e.g. in Europe) can be transported in the atmosphere even to Svalbard (Halbach et al. 2017). Therefore, this island is an important area for investigating long-range transport of heavy metals. Some data show that the heavy metal accumulation order for Arctic soils may be as follows: $\mathrm{Co}>\mathrm{Pb}>\mathrm{Cu}>\mathrm{Zn}>$ As $>\mathrm{Ni}>\mathrm{V}>\mathrm{Mn}$ and permissible levels of heavy metals are detected in these soils (Nikitina et al. 2015). 
Despite the extreme environmental conditions on Spitsbergen, many diverse microorganisms have colonized the water and land in this area. These microorganisms representing psychrophilic and psychrotolerant organisms have developed different mechanisms of adaptation to unfriendly environments, such as halotolerance, metal tolerance, and antibiotic resistance (Tomova et al. 2014). Thus, the population of polar microorganisms is worth investigating. Copiotrophic microorganisms grow at high nutrient concentrations and are unable to survive at nutrient limitations (Winiarczyk et al. 2014). In contrast to their strategy of growth, oligotrophic microorganisms are well adapted to extreme environmental conditions with low concentrations of nutrients and specialize in a slow growth rate (Wolińska et al. 2015). Few reports refer to the division of Arctic microorganisms into representing $\mathrm{r}$ and $\mathrm{K}$ strategies. It is generally accepted that Arctic organisms represent mainly passive-tolerant adaptive strategies ( $\mathrm{r}$ strategy) and rarely resistant-active type ( $\mathrm{K}$ strategy) (Shatlovich et al. 2009).

In mature soils, plant species and soil types determine the selection of the root microbiome, but which of these factors drives rhizosphere selection in the developing Spitsbergen soils has not yet been established (Mapelli et al. 2018). Spitsbergen provides a natural environment for identification of rhizosphere selection factors in developing soils. Moreover, the dynamics of microbial and plant responses to climate warming is still not well understood and needs characterization. Adaptation of microorganisms and plants to low temperatures and abiotic stresses (e.g. heavy metals) in the changing environment can contribute to understanding the global changes.

We have tested the hypotheses that a) the number of a culturable microbial community and microbial biodiversity (oligotrophic and copiotrophic bacteria and fungi) within the different rhizosphere soil habitats are uniform across Spitsbergen, b) the habitats are affected by the properties of soil and by plant species, c) there is a relationship between the content of heavy metals in soil and plants.

The aim of this study was to cross correlate data on physico-chemical parameters of soil with rhizosphere microorganisms and plant species in order to gain more knowledge about formation of the soil and development of plants in response to the changing climate on Spitsbergen and relations among them. With greater understanding of these correlations in vulnerable ecosystems, we may be able to predict future changes in advance.

\section{Materials and methods}

Study area

The study area was located in the High Arctic on Spitsbergen, the largest island of the Svalbard Archipelago. More specifically, it was Recherchefjorden, i.e. the NW part of Wedel Jarlsberg Land (WJL) situated in the SW area of Spitsbergen with geographical location described by NE coordinates (latitude, longitude) (Supplementary Fig. 1a; Electronic supplementary file).

In terms of the geological structure, the landform (geomorphological analysis) and the lithology of the sampling points were arranged into six areas: CAL Calypsostanda, POC - the extramarginal outwash plain of Renardbreen, REN - the inmarginal zone of Renardbreen (Renardbreen foreland), REIN Reinholmen, $\mathrm{CH}$ - the lower part of Chamberlindalen, and LN - the eastern coast of Recherchefjorden near Lægerneset (Table 1; Supplementary Figs. 1, 2).

The main four geological blocks, five units, morphology, cover sediments, granulometric fractions, and texture in the analysed areas were characterized and presented in Table 1, Supplementary Fig. 1b-g, 2, and Electronic supplementary file.

Meteorological data

The selected meteorological data were measured in the Maria Curie-Skłodowska University Polar Station in Calypsobyen (Supplementary Fig. 1a) in a multiyear period of 1986-2011 (Mędrek et al. 2014) and from 2012 to 2016 (Franczak et al. 2016; Mędrek et al. 2014; unpublished data) (Supplementary Table 1). The data showed an increase (except for 2012) in the minimum daily mean air temperature against the multiyear mean. Fluctuations of the maximum daily mean temperature were observed, from a decrease (2012-2014) to an increase (2015-2016) against the multiyear mean. The mean values of wind speed in 2014-2016 were slightly lower, but the decrease in the maximum daily mean was substantial. There were significant changes in precipitation values from a 3-fold increase in 2013 and 1.5-fold elevation in 2015 and 2016 to reduction in 2012 and 2014. 


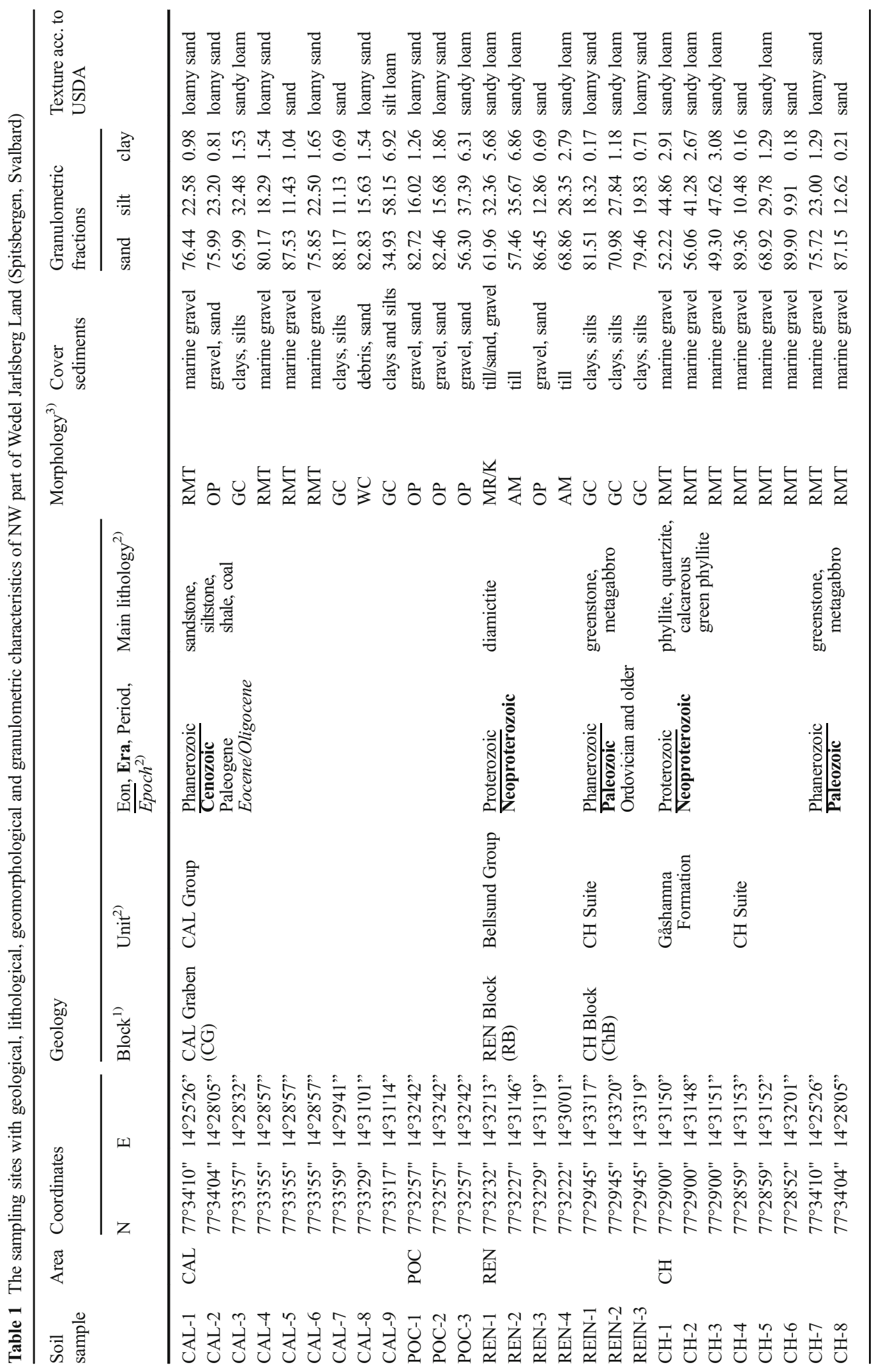


Soil and plant samples

Soil and plant samples were taken in July and August in 2014. Soil samples were collected from 32 different areas (Table 1, Supplementary Fig. 3) covered by vegetation (Table 2) in close vicinity of the plant root system. In each area, five soil samples were collected from the depth of $15 \mathrm{~cm}$, mixed together, dried and sieved $(<2 \mathrm{~mm})$.

Six species of vascular plants representing different types of life forms were identified in 21 sites with high coverage: Draba corymbosa DC (Dra), Dryas octopetala L. (Dry), Oxyria digyna (L.) Hill (Oxy), Salix polaris Wahlenb. (Sal), Saxifraga oppositifolia L. (Sax), and Silene uralensis (Rupr.) Bocquet (Sil) (Table 2, Supplementary Fig. 4, Electronic supplementary file). Mixed samples from five specimens of each species divided into shoots and roots were prepared, dried and homogenized.

The analyses of soil and plant samples were repeated three times.

Physico-chemical analysis of soil

The $\mathrm{pH}$ was measured potentiometrically in water (soil:water, 1:2.5) and $1 \mathrm{M} \mathrm{KCl} \mathrm{(soil:1} \mathrm{M} \mathrm{KCl}, 1: 2.5$ ). Soil hydrolytic acidity (exchangeable hydrogen; $\mathrm{Hh}$ ) was measured after extraction from $1 \mathrm{M} \mathrm{KCl}$ (van Reeuwijk 2002). The sum of total exchangeable bases (TEB) was determined using atomic absorption spectrophotometry (AAS, Agilent 240 FS F-AAS, Santa Clara, California, USA) after extraction from the soil with $1 \mathrm{M}$ ammonium acetate. Cation exchange capacity (CEC) of the soils was calculated as a sum of hydrolytic acidity and total exchangeable bases (van Reeuwijk 2002). The degree of base saturation (V\%) was calculated as a proportion of the sum of basic cations (TEB) to soil sorption capacity (CEC) multiplied by 100 . The soil texture was analysed using a Malvern Mastersizer analyser with a HydroG dispersion unit (Mastersizer MS-2000, UK) and the soil taxonomy was based on USDA (United States Department of Agriculture, Soil Survey Staff 2006).

Samples for chemical analyses were prepared according to the procedure proposed by Agrawal et al. (1991). Calcium carbonate content was assessed with Scheibler's volumetric method with the use of a Calcimeter (Eijkelkamp Soil \& Water, Giesbeek, Nederland) (Williams 1949). The total organic carbon 
$(\mathrm{C}-\mathrm{t})$ and total nitrogen $(\mathrm{N}-\mathrm{t})$ contents were determined using a LECO CNS elementary analyser (LECO Truspec CN, USA). Plant-available P and K in the soil were extracted with the calcium lactate Egner-Riehm method (Egner et al. 1960) and determined using UVViS spectrophotometry (Perkin-Elmer, Model Lambda 12, Waltham, Massachusetts, USA) and F-ASS technique (Agilent 240 FS F-AAS, Santa Clara, California, USA), respectively.

Heavy metal analysis in the soil and plants

Soil and plant samples (shoots and roots rinsed in distilled water) were dried first on air and afterwards at $105^{\circ} \mathrm{C}$ to constant weight. In order to determine the pseudototal (hereafter referred to as total) content of heavy metals, the soil and plant samples were dissolved with aqua regia (ISO 11466 1995). Trace elements in the soil extracts were determined using the F-AAS technique (Agilent 240 FS F-AAS, Santa Clara, California, USA).

Quality control in the soil and plants

The accuracy of the determination of C-t and N-t in the soil was tested against certified reference material (calibration soil sample ref. no. 502-062, LECO Corporation is A2LA accredited in accordance with the International Standards Organization ISO/IEC 17025:2005 - Certificate No. 3285.01).

Analyses of heavy metals were carried out based on reference soil samples, SO-2, and SO-4 from the Canada Centre for Mineral and Energy Technology. The detection limits for F-AAS expressed in $\mu \mathrm{g} \mathrm{L}^{-1}$ were as follows: 1.5 for $\mathrm{Cd}, 3$ for $\mathrm{Cu}, 6$ for $\mathrm{Cr}, 10$ for $\mathrm{Ni}$ and $\mathrm{Pb}$, and 1 for $\mathrm{Zn}$. The precision of the analyses was within the range of approximately $1.9 \%$ to approximately $8.0 \%$ (e.g. $1.87 \%$ for $\mathrm{Cu} ; 2.12 \%$ for $\mathrm{Cd} ; 2.22 \%$ for $\mathrm{Pb} ; 3.04 \%$ for $\mathrm{Zn}$; $7.4 \%$ for $\mathrm{Cr}$, and $7.2 \%$ for $\mathrm{Ni}$ ).

Assessment of pollution in the soil and plants

The degree of heavy metal contamination of the soil and plant tissues was determined by calculation of the geoaccumulation index $\left(\mathrm{I}_{\text {geo }}\right)$, enrichment factor $(\mathrm{EF})$ (Tables 3 and 4), and pollution load index (PLI) for the soil. $\mathrm{I}_{\text {geo }}$ was calculated according to the equation: $\mathrm{I}_{\text {geo }}=$ $\log _{2}\left[C_{n} / 1.5 \times B_{n}\right]$, where $C_{n}$ is the measured concentration of the metal and $\mathrm{B}_{\mathrm{n}}$ is the geochemical background of the metal (Muller 1969). This index divides the soil and plants into seven classes: 0 - uncontaminated $\left(\mathrm{I}_{\text {geo }} \leq 0\right) ; 1$ - uncontaminated to moderately contaminated $\left(0<\mathrm{I}_{\text {geo }} \leq 1\right) ; 2$ - moderately contaminated $(1<$ $\left.\mathrm{I}_{\text {geo }} \leq 2\right) ; 3$ - moderately to heavily contaminated $(2<$ $\left.\mathrm{I}_{\text {geo }} \leq 3\right) ; 4$ - heavily contaminated $\left(3<\mathrm{I}_{\text {geo }} \leq 4\right) ; 5$ heavily to extremely contaminated $\left(4<\mathrm{I}_{\text {geo }} \leq 5\right) ; 6-$ extremely contaminated $\left(\mathrm{I}_{\text {geo }} \geq 5\right)$.

EF was estimated as $\mathrm{EF}=\left[\mathrm{C}_{\mathrm{x}} / \mathrm{C}_{\mathrm{ref}}\right]_{\text {sample }} /\left[\mathrm{C}_{\mathrm{x}} /\right.$ $\left.\mathrm{C}_{\text {ref }}\right]_{\text {background }}$, where $\mathrm{C}_{\mathrm{x}}$ is the measured concentration of the metal and $\mathrm{C}_{\mathrm{ref}}$ is the concentration of the reference element for normalisation (Dragović et al. 2008). This factor was calculated choosing Fe (2.49\%; Ottesen 2015) as a reference element. According to EF, the soil and plants are classified into five contamination categories: 1 - deficiency to minimal enrichment $(\mathrm{EF}<2) ; 2$ - moderate enrichment $(\mathrm{EF}=2-5) ; 3-$ significant enrichment $(\mathrm{EF}=5-20) ; 4-$ very high enrichment $(\mathrm{EF}=20-40) ; 5-$ extremely high enrichment (EF > 40).

PLI for the soil was calculated as follows: $\mathrm{PLI}=\left(\mathrm{CF}_{\mathrm{Cr}} \times \mathrm{CF}_{\mathrm{Ni}} \times \mathrm{CF}_{\mathrm{Cu}} \times \mathrm{CF}_{\mathrm{Zn}} \times \mathrm{CF}_{\mathrm{Cd}} \times \mathrm{CF}_{\mathrm{Pb}}\right)^{1 / 6}$, where $\mathrm{CF}$ is the contamination factor obtained by calculating the difference between the concentration of each metal and its geochemical background value (Tomlinson et al. 1980). Based on PLI, there are two categories: the presence $(\mathrm{PLI}>1)$ or absence $(\mathrm{PLI}<1)$ of contamination.

The biological accumulation factor (BAF) was calculated with the equation: $\mathrm{BAF}=\mathrm{C}_{\mathrm{S}} / \mathrm{C}$, where $\mathrm{C}_{\mathrm{S}}$ is the metal concentration in the plant shoot $(\mathrm{S})$ and $\mathrm{C}$ is the metal concentration in the soil. The bioconcentration factor $(\mathrm{BCF})$ was estimated as follows: $\mathrm{BCF}=\mathrm{C}_{\mathrm{R}} / \mathrm{C}$, where $C_{R}$ is the ratio of the metal concentration in the plant root $(\mathrm{R})$ and $\mathrm{C}$ is the metal concentration in the soil. The translocation factor $(\mathrm{TF})$ was defined as $\mathrm{TF}=$ $C_{S} / C_{R}$, where $C_{S}$ and $C_{R}$ are the metal concentrations in $\mathrm{S}$ and $\mathrm{R}$, respectively. TF allows measuring plant effectiveness in translocating the metal from roots to leaves.

Microbiological analysis of the soil

The assessment of number and biodiversity of microorganisms was carried out in 21 rhizosphere soil samples, whose weight was sufficient for performing microbiological analysis. In eight of the tested soil samples (POC-2, REIN-2, CH-3, -5, -6, -8 and LN-2, -3), plant communities were not determined due to the absence of dominant species. The number of three groups of microorganisms, i.e. oligotrophs, copiotrophs, and fungi, 
was determined with the soil dilution technique and expressed as colony forming units (CFU) per gram of dry weight of soil. Copiotrophs were cultivated on PYS agar (Alef 1995), oligotrophs on 100-fold diluted PYS, and fungi on Martin medium (Martin 1950). The cultivations were performed for 21 days at $20{ }^{\circ} \mathrm{C}$. The biodiversity of microorganisms was presented as the ecophysiological diversity index (EP) and the colony development index (CD). The EP index was calculated as follows: $E P=-\Sigma\left(p_{i} \times \log 10 p_{i}\right)$, where $p_{i}$ is the population in class $i$ to the total population for each of the colonies appearing on each of the 21 days (De Leij et al. 1993; Kotsou et al. 2004). It ranges from 0 to 1 and reaches 1 when the same number of colonies appears on each day over 21 days. The EP index is a determinant of the number of classes of microorganisms and the number of microorganisms in each class. A high EP value indicates a large diversity - a large number of classes and a similar number within the classes. The $\mathrm{CD}$ index was expressed as $\mathrm{CD}=[\mathrm{N} 1 / 1+\mathrm{N} 2 / 2+\ldots+\mathrm{N} 21 / 21] \times 100$, where $\mathrm{N}_{1}, \mathrm{~N}_{2}$, and $\mathrm{N}_{21}$ are the proportions of bacterial colonies appearing on days 1, 2, and 21 (Sarathchandra et al. 1997). It ranges from 10 to 100 and achieves 100 when all colonies of microorganisms have grown after $24 \mathrm{~h}$. High CD values indicate a larger share of a group of microorganisms with the $\mathrm{r}$ strategy and low values indicate the K strategy.

\section{Data analysis}

All the statistical analyses were carried out using Statistica 6.1 (Stat Soft. Inc.) and were expressed as the average value $\overline{\mathrm{X}}$ with standard deviation (SD). Responses of the microorganisms and plant species to the concentration of heavy metals in the soils were evaluated with multivariate methods in the MVSP 3.21 package (Kovach 1999). The collected data (21 samples were used to compare the soil properties with microbiology and 21 to compare the soil properties with heavy metals in plants) were analysed statistically after standardisation. Based on the length of the data gradient (1.8-0.9 SD), the principal component analysis (PCA) was carried out. The concentration of heavy metals in the soil and plant samples and the relationship between them (BAF, BCF) were regarded as independent variables, as well as the number of the three groups of microorganisms and the EP and CD factors. All analyses were based on the average values of variables for a given sample.

\section{Results}

Soil analysis

The research area was characterized by diversified soil cover with Haplic Cryosols, Reductaquic Cryosols, Hyperskeletic Cryosols, and Leptic Regosols (IUSS Working Group WRB 2015) (Table 1). In our study, the alkaline $\mathrm{pH}\left(7.8-8.5\right.$ in $\mathrm{H}_{2} \mathrm{O}$ and $7.5-8.5$ in $\left.\mathrm{KCl}\right)$ was related to the presence of carbonates in the soil material (from 6.0 to $37.3 \%$ ). $\mathrm{CaCO}_{3}$ was detected in the POC, REN, and partially CAL samples (Table 2). These samples were characterized by almost full saturation of the sorption complex with basic cations. Soils that did not contain carbonates were characterized by acidic to neutral $\mathrm{pH}\left(5.1-7.3\right.$ in $\mathrm{H}_{2} \mathrm{O}$ and 4.9-7.0 in $\mathrm{KCl}$ ) and demonstrated higher $\mathrm{C}$-t content in REIN and LN. The highest Hh values accompanied the highest CEC values. The highest values for both parameters were measured in REIN-2 and 3. The variability of $\mathrm{V}$ reached from 71.1 to $99.5 \%$. Lower values of $\mathrm{V}$ were noted in soils where $\mathrm{CaCO}_{3}$ was not detected and were mostly accompanied by a high Hh value (Table 2 ).

The studied soils were incipient soils with poorly formed profiles and a large proportion of skeletal parts. In our research, sites abundant in both coarser material (sand and loamy sand texture - 17 samples) and silt and clay fractions (silt loam and sandy loam texture -15 samples) were often very closely located. Almost all the soil surface horizons in our research were characterized by predominance of the sand fraction, ranging from $34.9 \%$ to $87 \%$, whereas the content of the clay fraction was very low, ranging from $0.2 \%$ to $6.9 \%$ (Table 1 ).

Determination of the relationship between the geological structure and the lithology of the bedrock as well as the physico-chemical properties of the soils in the sampling areas was problematic. In some part of the area, the lithological situation was complicated by the fact that a thick series of late deposits in the form of two generations of tills separated by marine mud and sand. Other areas seemed to be less non-homogeneous.

The C-t content was high, reaching mostly from 3 to $5 \%$. The C-t values were higher than $10 \%$ for five samples (between 12 and 30\%), and lower than $1 \%$ for only three samples. Soils occurring in the quite poor tundra environment were characterized by varied content of C-t (0.74-31.15\%) and N-t (not detected-1.71\%), and hot spots with high $\mathrm{C}-\mathrm{t}$ and $\mathrm{N}-\mathrm{t}$ content were found in the REIN and LN locations (Table 2). Generally, the tested 


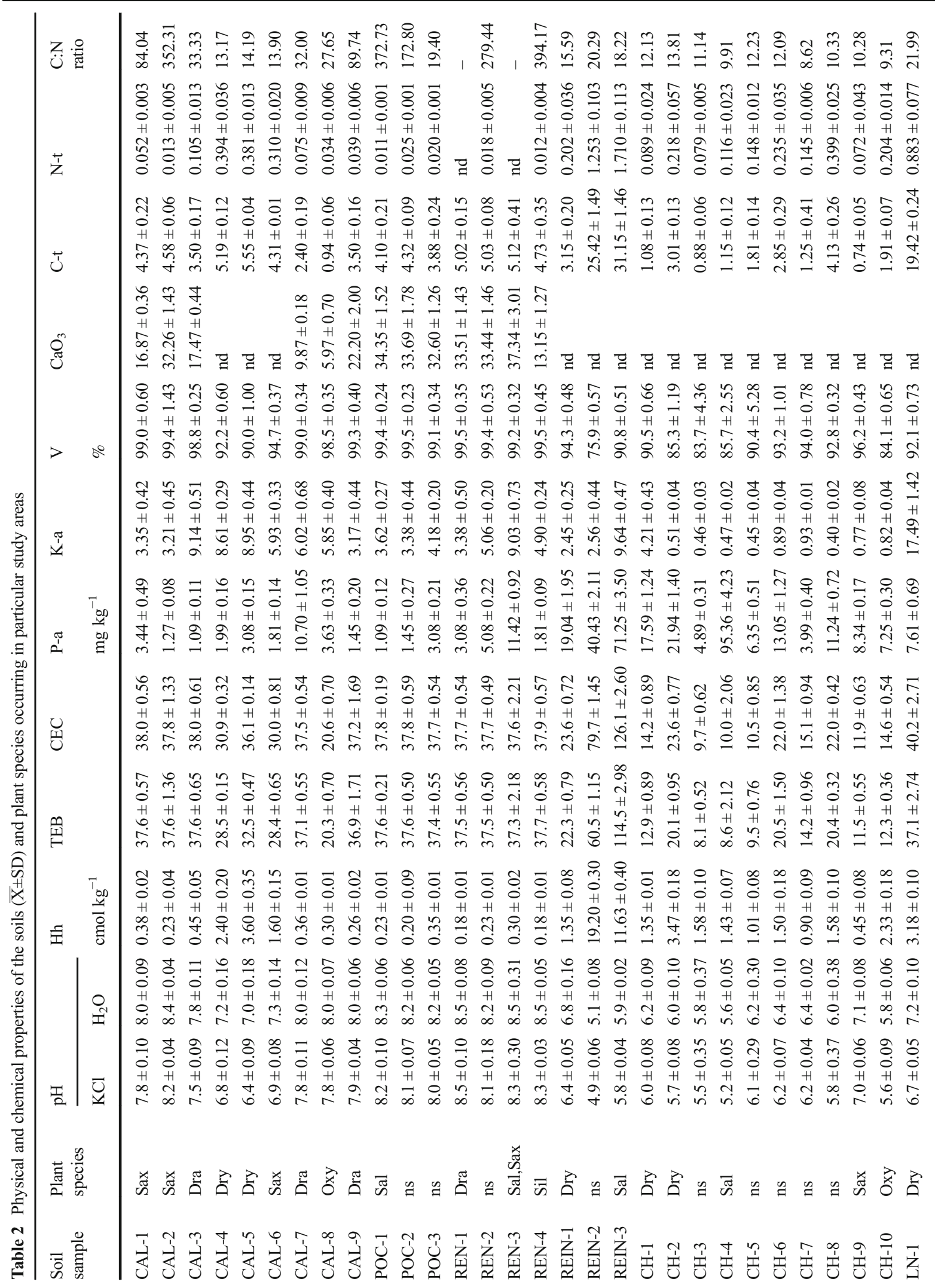




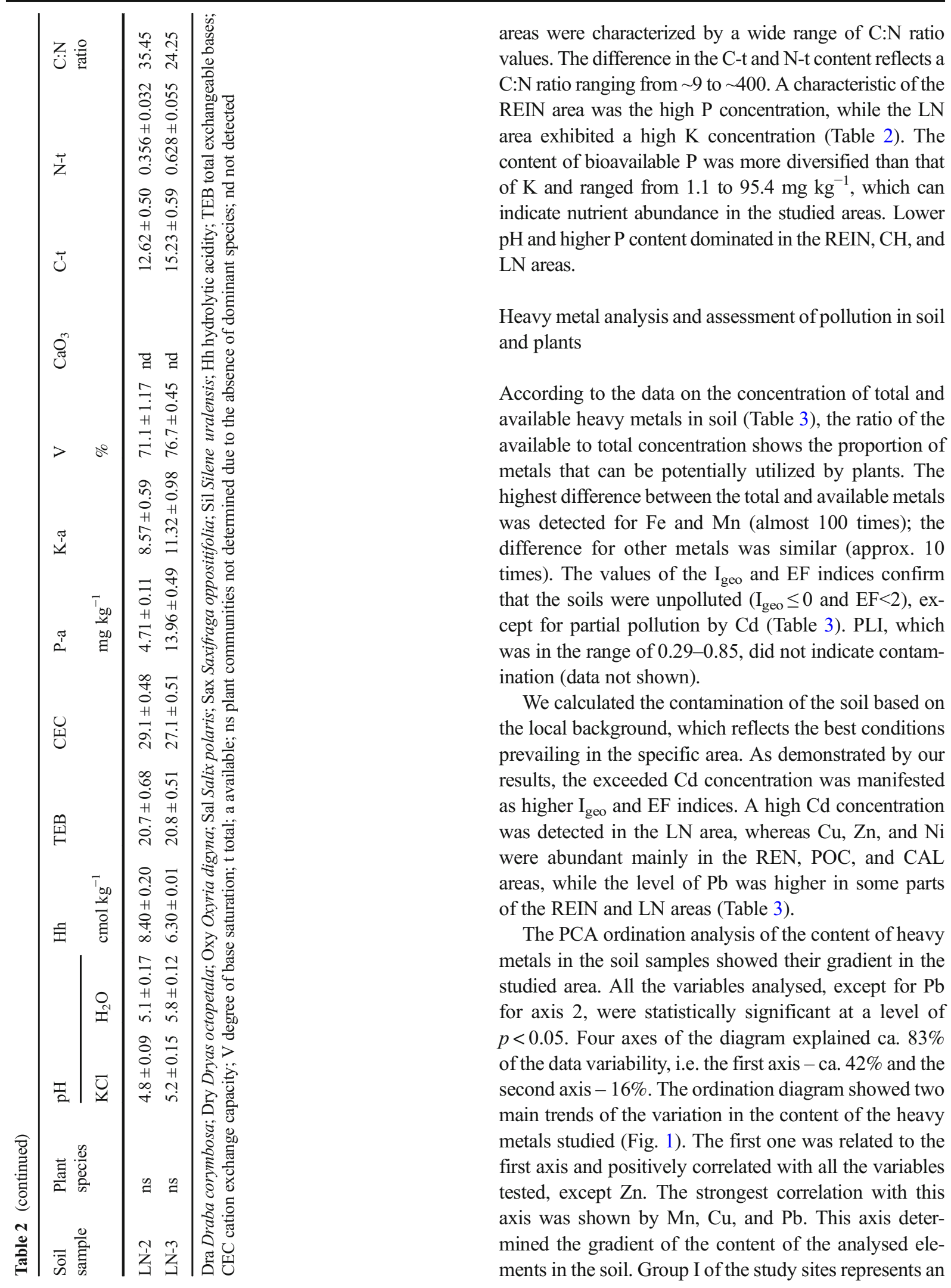


increasing content of $\mathrm{Fe}, \mathrm{Cr}, \mathrm{Cu}, \mathrm{Mn}$, and $\mathrm{Pb}$, starting from the $\mathrm{CH}-1$ and $\mathrm{CH}-2$ to $\mathrm{CAL}-6$ and CAL-9. Group II was negatively correlated with the first axis; it exhibited high content of $\mathrm{Zn}$ and low content of the other metals. The second axis of the PCA ordination diagram was strongly positively correlated with content of $\mathrm{Cd}$, and this axis determined the gradient of $\mathrm{Cd}$ in the studied soil (Group III). The Cd content decreased from the CAL-5 and CAL-6 (located above the 2nd axis and positively correlated with it) to CAL-7 and REN-1 (negatively correlated with the discussed axis), where the lowest content of $\mathrm{Cd}$ was recorded.

The concentration of heavy metals in plant tissues and the $I_{\text {geo }}$ and EF indices are presented in Table 4. The highest concentrations were reported for $\mathrm{Fe}$, followed by $\mathrm{Mn}$ and $\mathrm{Zn}$, and the lowest content was detected for Cd (Table 4). The values of the $I_{\text {geo }}$ index showed that 7 samples belonged to class 1,3 - to class 2 , and 1 - to class 4 in the case of Cd (Table 4). For Zn, 7 samples were categorized as class 1 of the $I_{\text {geo }}$ index and 1 - as class 2 . Two samples represented class 1 in the case of $\mathrm{Pb}$ and 1 sample belonged to class 1 for Fe. The calculations of EF for the plant tissues showed that, in the case of $\mathrm{Cd}, 5$ samples belonged to category 2, demonstrating moderate enrichment (Salix shoots in the POC-1 and CH-4 area, Salix roots in REIN-3, Dryas shoots in CH-2) and 1 sample was categorized into class 3, indicating significant enrichment (Salix shoots in REIN-3). For Zn, 3 samples belonged to category 2 (Salix shoots in CH-4 and REIN-3).

In PCA, all analysed variables, except $\mathrm{Pb}$ for axis 1 , were statistically significant at a level of $p<0.05$ (Fig. 2a). Four axes of the diagram explain ca. $86 \%$ of the data variability, including the first axis - ca. $34 \%$ and the second axis $-28 \%$. The first axis is the most important for the data distribution and is strongly positively correlated with the average content of $\mathrm{Zn}, \mathrm{Cu}$, and $\mathrm{Cd}$. The second axis of the ordination diagram was strongly positively correlated with the average content of Fe and $\mathrm{Cr}$ and determined the gradient of accumulation of these heavy metals in the tested plant material. This phenomenon was visible in the decreasing content of $\mathrm{Fe}$ and $\mathrm{Cr}$ from CH-2 in Dry to CAL-1 in Sax (Fig. 2a).

The values of $\mathrm{BAF}, \mathrm{BCF}$, and $\mathrm{TF}$ are presented in Supplementary Table 2. The BAF index showed the highest amount of transported $\mathrm{Zn}$ (8 cases), followed by $\mathrm{Cd}$ (5), $\mathrm{Ni}$ (3), and $\mathrm{Pb}$ (3), and similar amounts of $\mathrm{Zn}$ and $\mathrm{Cd}(1)$. The BCF index showed that $\mathrm{Cd}$ and $\mathrm{Ni}$ were transported mostly in the same number of cases ( 3 cases each) as well as $\mathrm{Zn}$ (2 cases). As shown by TF, $\mathrm{Cd}$ and
$\mathrm{Pb}$ (2 cases each) were transported most efficiently from roots to shoots, followed by $\mathrm{Zn}$ and $\mathrm{Cr}$ (1 case each), and $\mathrm{Ni}$ with the least efficient transport.

The BCF and TF indices were examined in the next PCA ordination analysis (Fig. 2b). It showed statistical significance of all tested variables, except for $\mathrm{Cu}$ for the first axis and $\mathrm{Cr}$ for the second one. The first axis of the ordination diagram explained $31 \%$, the second - ca. $21 \%$, and 4 axes - ca. $82 \%$ of the data variation. The first axis was correlated positively with the $\mathrm{Zn}$ and $\mathrm{Cd}$ content in the plant material and negatively with the $\mathrm{Fe}$, $\mathrm{Cr}$, and $\mathrm{Mn}$ content. The second axis was strongly positively correlated with the $\mathrm{Cu}, \mathrm{Zn}$, and $\mathrm{Ni}$ content and negatively correlated with $\mathrm{Pb}$ and $\mathrm{Mn}$.

Analysis of microorganisms

Compared with copiotrophs, the same or a slightly lower number of oligotrophs was observed. Only in CAL-3, 7 (Dra rhizosphere), POC-2, and REIN-2, an approximately $1 \log _{10}$ lower number of oligotrophs was detected (Fig. 3a).

We obtained high EP indices for copio- and oligotrophs, and the lowest EP values for fungi (Fig. 3b). The CD values were low and did not exceed 40 . The highest values of this index were achieved mainly by fungi, and the lowest index was noted mainly for oligotrophs (Fig. 3c). Overall, the small number of fungi corresponded with the low EP index and the high CD index, whereas a reverse relationship was noted in bacteria. This indicates that the average number of fungi was inversely proportional to the number of bacteria. The exceptions, CAL-4 and CAL-7, were characterized by a high average number of all groups of microorganisms.

The PCA ordination analysis facilitated determination of the relationships between the average number of microorganisms (oligo-, copiotrophs, and fungi) (Fig. 4a). All analysed variables were statistically significant at a level of $p<0.05$. The first axis explaining ca. $83 \%$ of the data variability had the greatest importance for the data distribution. The first axis revealed the rising share of microorganisms in the soil, whose number was positively correlated with this axis. The ordination diagram showed an increase in the average number of oligo- and copiotrophs from CAL-1 to CAL-6 on the left side of the diagram (Fig. 4) and the relationship between them.

The occurrence and share of microorganisms in the examined material were also shown by means of the EP and $\mathrm{CD}$ indices, which were dependent variables in the 


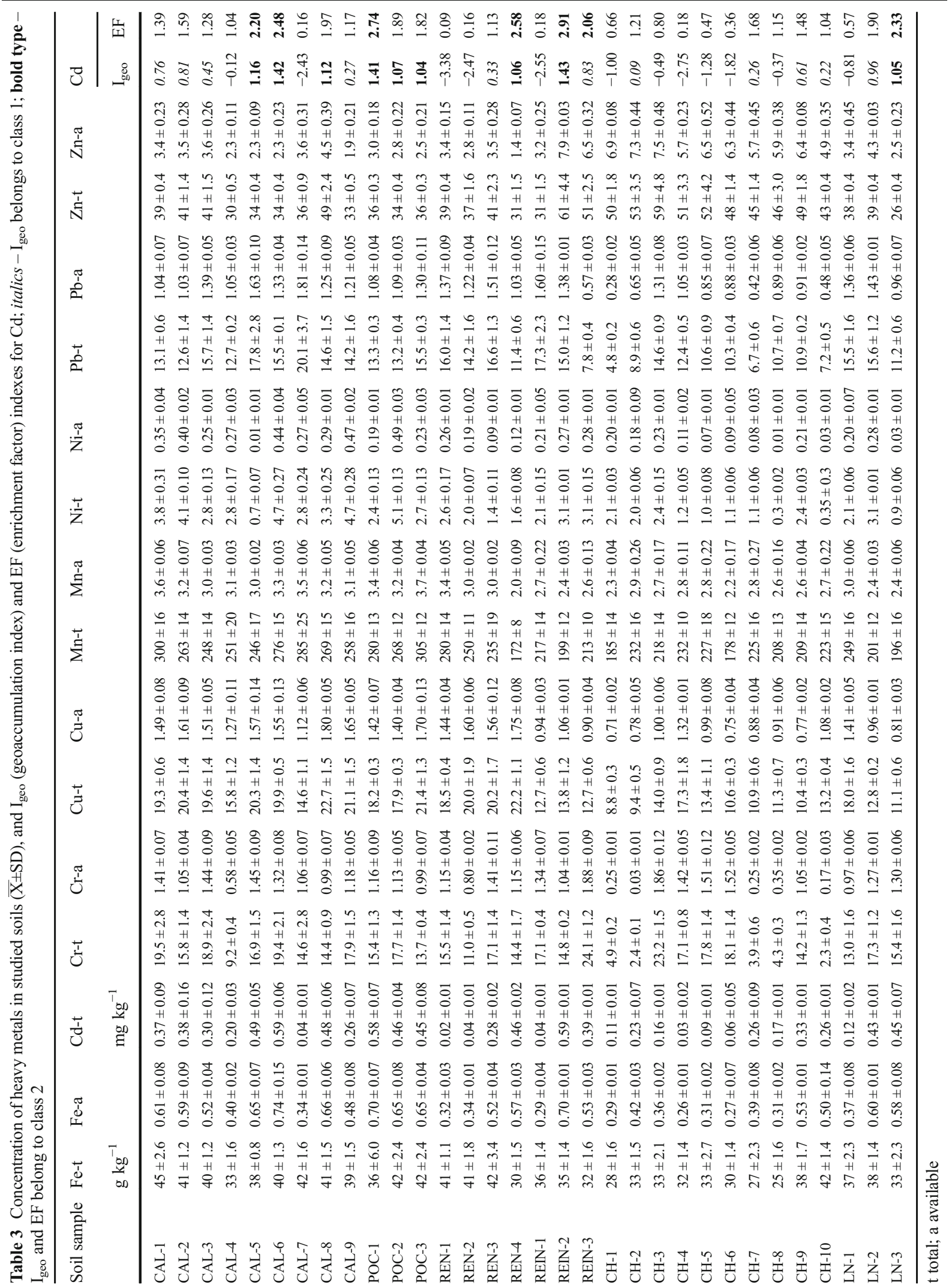




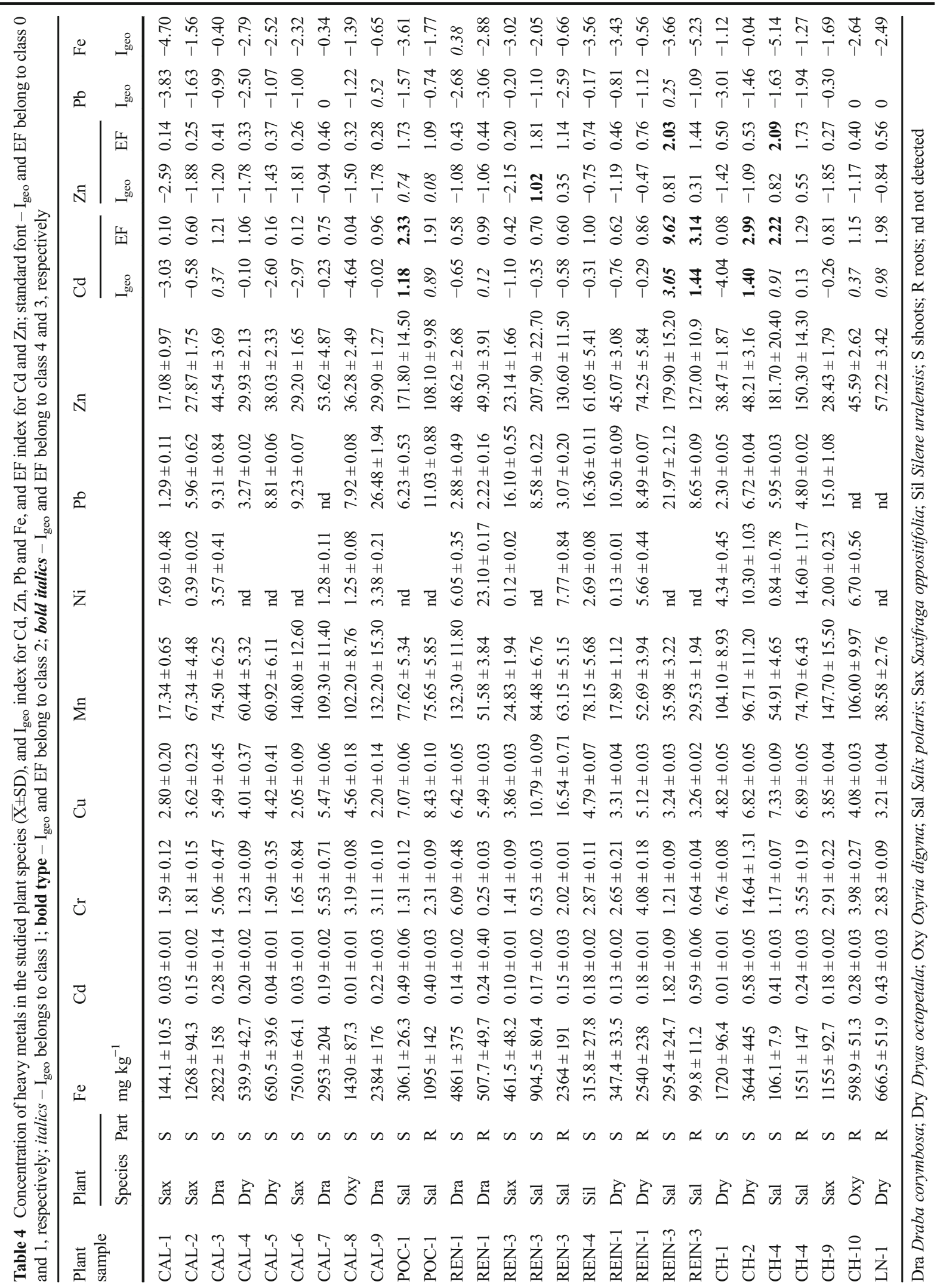


PCA analysis (Fig. 4b). The EP and CD were statistically significant for the first and second axis of the ordination diagram and explained ca. $36 \%$ and $29 \%$ of the data variability, respectively. The EP for oligo- and copiotrophs was most strongly positively correlated with the first axis, but the $\mathrm{CD}$ was negatively correlated for the analysed groups of bacteria. The study sites negatively correlated with the first and/or the second axis, e.g. CAL1,3 , and 9 as well as CH-2 and 3 were characterized by low values of EP and CD for bacteria. High values of the analysed indices were observed in sites positively correlated with axis 1, e.g. CAL-7, CH-8, LN-1, and POC-1. In most cases, the high or medium EP values for bacteria were associated with the low values of this coefficient for fungi, except for REIN-2, where the EP values for copiotrophs and fungi had the highest values in the analysed material. The low values of $\mathrm{CD}$ for fungi in CAL-5 and 9 as well as CH-2 coincide with the low values for bacteria. The highest values of $\mathrm{CD}$ were recorded in CH-8, REIN-3, and CH-6 and were positively correlated with axis 2 . The second axis of the ordination diagram determined the $\mathrm{CD}$ gradient for fungi.

\section{Discussion}

\section{Characteristics of soil}

The diversified texture of the soil occurring in close vicinity may be interpreted as local differentiation in sedimentation and/or contemporary periglacial processes, e.g. cryoturbation, solifluction, and gelifluction (Szymański et al. 2015). Soils formed from different materials also exhibit variable content of stone, gravel, sand, silt, and clay fractions. However, as noted in Klimowicz et al. (2009), most of the soil surface horizons in our research were characterized by predominance of the sand fraction, and the content of the clay fraction was very low (Table 1). Soil texture influences heat propagation in the ground; thus, since sandy soils exhibit the highest rate of thawing, the thickness of the active layer is also the highest.

Generally, the tested areas were characterized by a high $\mathrm{C}: \mathrm{N}$ ratio, which demonstrated different stages of organic matter decomposition in soils (Table 2). The wide range of $\mathrm{C}: \mathrm{N}$ ratio values may indicate different stages of development of the Spitsbergen soils. The lowest $\mathrm{C}: \mathrm{N}$ values were found in the REIN, $\mathrm{CH}$, and LN locations, which are characteristic for welldistributed soil humus. In most samples, the $\mathrm{C}: \mathrm{N}$ ratio was in the range from 10 to 30, which corresponds with that in mature soil. Similar C:N ratios calculated for soils in Spitsbergen were reported by Dziadowiec et al. (1994) and Solheim et al. (1996). Low pH corresponded with high $\mathrm{P}$-a content and dominated in the REIN, $\mathrm{CH}$, and LN areas (Table 2), which can be partially explained by the presence of seabird guano. Alkaline guano is converted into nitrate and oxalic acid decreasing soil pH (Szymański et al. 2015). Organic and inorganic acids have an influence on the solubility of insoluble P compounds and determine the bioavailability of $\mathrm{P}$ resources (Kurek et al. 2013). Similar concentration of K-a in

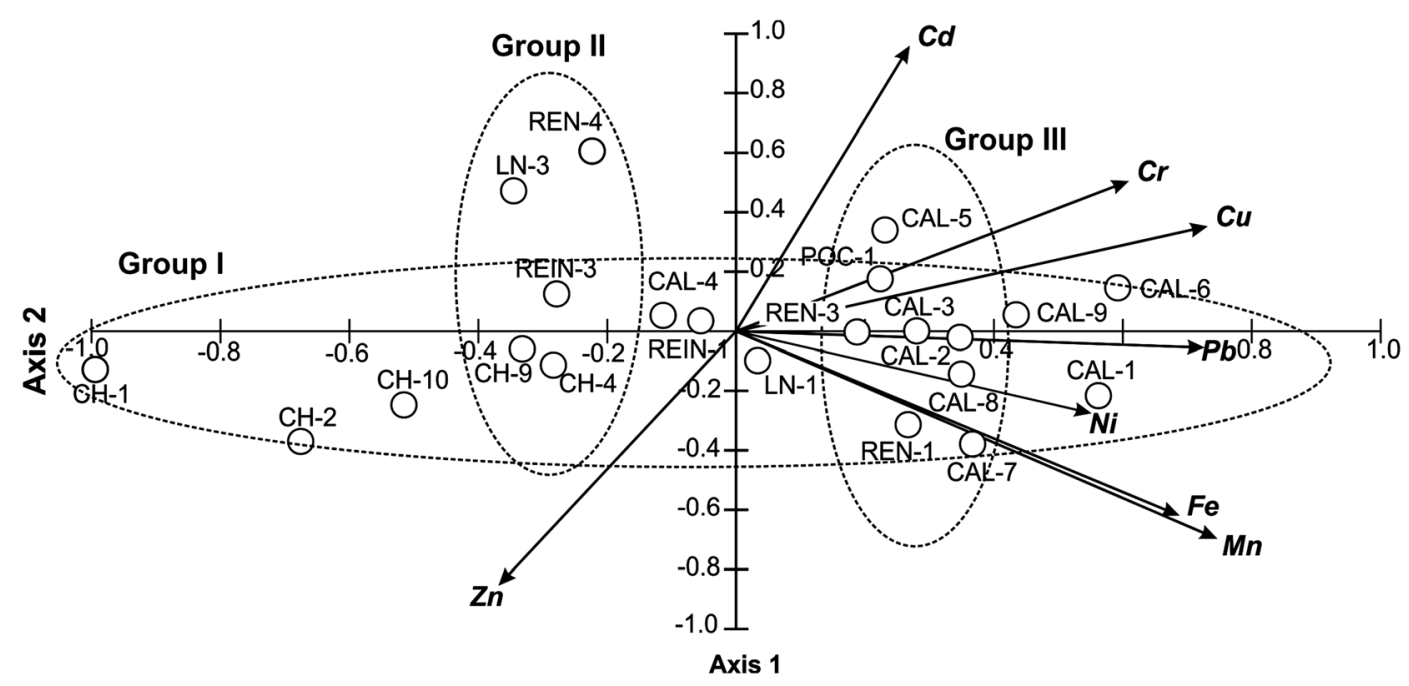

Fig. 1 Ordination diagram showing the result of the PCA for the heavy metal content in soil. Eigenvalues: Axis 1-6.36, Axis 2-2.47. Other abbreviations as in Table 1 


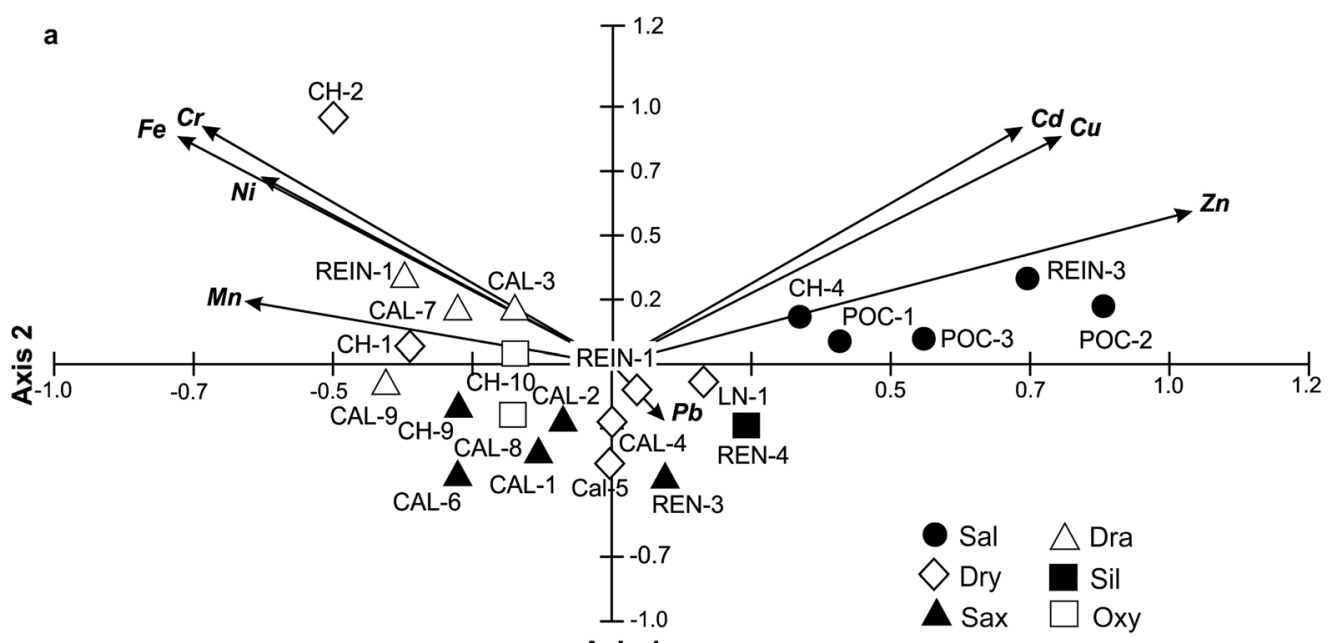

Axis 1
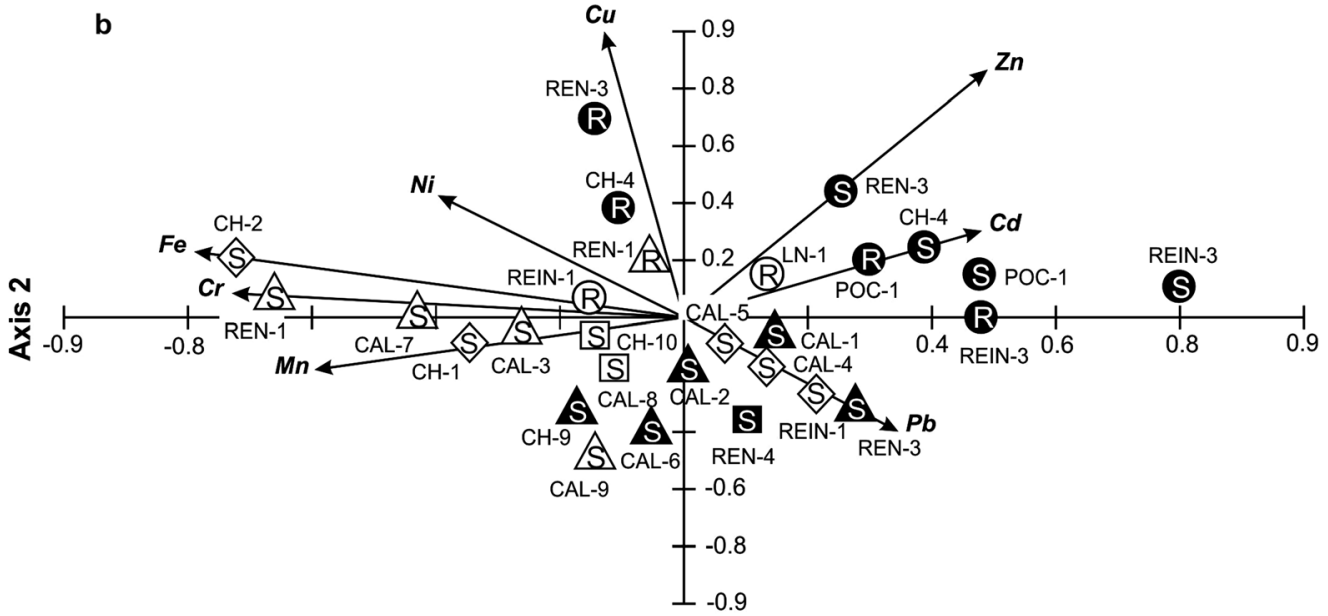

Axis 1

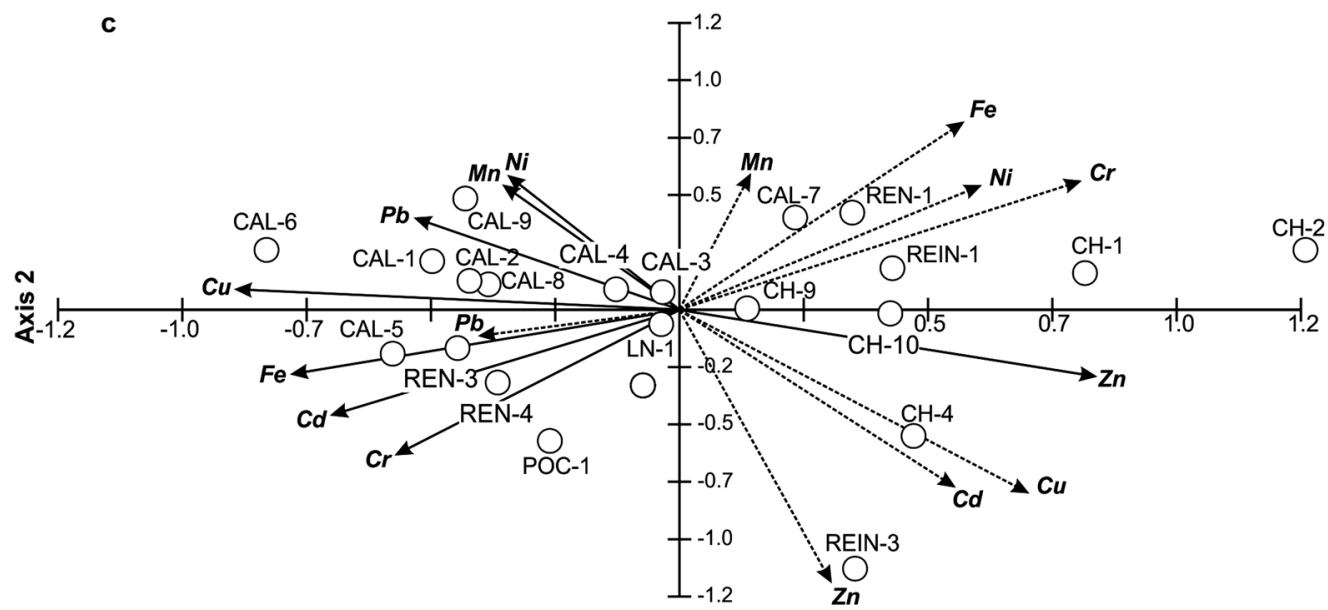

Axis 1 
Fig. 2 Ordination diagram showing the result of the PCA for plant: a the heavy metal content. Eigenvalues: Axis 1-2.70, Axis 2-2.50. b Translocation of the studied heavy metals in plant organs: shoots $(\mathrm{S})$ and/or roots $(\mathrm{R})$ expressed as the $\mathrm{BCF}$ and $\mathrm{TF}$ indices. Eigenvalues: Axis 1-2.48, Axis 2-1.70. c Comparison of the content of heavy metals in the soil (dashed line) and plant (plane line) samples. Axis 1-4.93, Axis 2-2.65. Other abbreviations as in Table 1

Spitsbergen soil was reported by Klimowicz and Uziak (1988). All the analysed soils developed from heterogeneous parent material, which is the explanation for their chemical diversity.

Heavy metals in the soil and plants

In contrast to the findings reported by Nikitina et al. (2015), the order of heavy metal accumulation in the soil was as follows: $\mathrm{Mn}>\mathrm{Zn} \geq \mathrm{Fe}>\mathrm{Cu}>\mathrm{Pb}>\mathrm{Ni}>\mathrm{Cd}$ for the total content, $\mathrm{Zn}>\mathrm{Mn} \geq \mathrm{Pb} \geq \mathrm{Cu}>\mathrm{Cr}>\mathrm{Fe}>\mathrm{Ni}$ (Table 3) for the available forms, and $\mathrm{Fe}>\mathrm{Zn} \geq \mathrm{Mn}>$ $\mathrm{Ni} \geq \mathrm{Pb}>\mathrm{Cu} \geq \mathrm{Cd}$ in plant tissues (regardless of the shoots and roots) (Table 4). As demonstrated by this rank, the location of $\mathrm{Cd}$ and $\mathrm{Pb}$ in the order of the total content of heavy metals accumulated in the soils and plants was the same. In the plants, high $\mathrm{Zn}$ and $\mathrm{Mn}$ concentrations were detected, which reflected the highest concentrations of available $\mathrm{Zn}$ and $\mathrm{Mn}$. The $\mathrm{I}_{\text {geo }}$ index seems to be more sensitive than EF and PLI in showing alleviation of the heavy metal concentration in the soil (Table 3). In our research, the exceeded $\mathrm{Cd}$ concentration was manifested as the higher $\mathrm{I}_{\text {geo }}$ and $\mathrm{EF}$ indices, which was consistent with the results reported by Hao et al. (2013). The source of heavy metals is mostly associated with long-range atmospheric transport, coal combustion, and bedrock geology, and is partially dependent on the local rock type (Gulińska et al. 2003; Kosek et al. 2018). On the one hand, the higher $\mathrm{Cd}$ concentration was related much more strongly to airborne pollutants from Europe, North America, and Asia than to the geology of the bedrock (Ottesen 2015). Wind can bring pollution from different and distant areas. The dominating wind directions vary from season to season, e.g. they were W, NE, and E in 2014 (Mędrek et al. 2014), and ENE, NW, E, and WNW in 2015 (unpublished data). Moreover, the sea aerosol can be a source of heavy metals such as $\mathrm{Pb}$ (Kłos et al. 2017). On the other hand, the high $\mathrm{Cd}$ concentration can be connected with the Triassic bedrock (Ottesen 2015), as in the $\mathrm{LN}$ area, whereas $\mathrm{Cu}, \mathrm{Zn}$, and $\mathrm{Ni}$ are abundant mostly in basic igneous rocks - mainly the REN, POC, and CAL areas, while acid igneous rocks are rich in $\mathrm{Pb}$ (Ottesen et al. 2010) - partially in the REIN and LN areas. The vicinity of the seabird colony elevated the concentrations of some heavy metals, such as $\mathrm{Zn}, \mathrm{Mn}, \mathrm{Cu}$, and $\mathrm{Cd}$ (Ziółek et al. 2017). In the alkaline environment (e.g. CAL, POC, and REN), metals can reduce mobility in three ways: forming precipitates, elevating the number of available absorption sites, and lowering the competition of $\mathrm{H}^{+}$for absorption (Krajcarová et al. 2016).

Our results support the hypothesis of a restricted human impact on the distribution of heavy metals in Spitsbergen. The local distribution was confirmed by the absence of long-distance transport of heavy metals, which agrees with the findings reported by Gulińska et al. (2003).

The PCA analysis for the average content of the investigated metals in the plant material showed their diversity and dependence on the life form and persistence of the species (Fig. 2a). The highest accumulation of $\mathrm{Zn}, \mathrm{Cu}$, and $\mathrm{Cd}$ was recorded in the perennial woody species Salix polaris and Dryas octopetala.

It was demonstrated that the examined metals were more strongly accumulated in the shoots and roots of the woody perennials compared to the herbaceous plants (Fig. 2b). This relationship applies to both above- and underground organs (Table 4). The uptake of metals by plants can be determined by plant biomass, e.g. increased biomass can dilute the metal concentration, which is responsible for incorrect determination of metal concentrations (Wojtun et al. 2013).

\section{Relationships between soil and plants}

The PCA analysis compared the content of heavy metals in the soil (Fig. 1) and plant samples (Fig. 2c). All the variables analysed were statistically significant at a level of $p<0.05$, except for $\mathrm{Mn}$ in the plants for axis $1, \mathrm{~Pb}$ in the plants for axis 2 , and $\mathrm{Cu}$ in the soil for axis 2 . The four axes of the diagram explained ca. $71 \%$ of data variability, including the first axis - ca. $31 \%$ and the second one $-16 \%$. In general, the first axis of the ordination diagram was positively correlated with the content of heavy metals in the plant samples, except $\mathrm{Pb}$, and negatively correlated with metals in the soil, except $\mathrm{Zn}$. Our results show differences in the concentration of 
heavy metals in the studied soils and plants (Fig. 2c). It was found that the various plant life forms accumulate metals differently, e.g. the highest content of $\mathrm{Fe}$ and $\mathrm{Cr}$ was recorded in the herbaceous perennial plants Draba oxycarpa, Saxifraga oppositofolia, and woody perennial Dryas. In the herbaceous plants, relatively high $\mathrm{Ni}$ content was observed as well. Similar to the report presented by Wojtuń et al. (2013), our data show that Salix polaris was the best accumulator of elevated levels of Cd and Zn.

\section{Microbial abundance and diversity}

The genetic differences between microorganisms enable them to adjust to changes in the environment and to survive (De Leij et al. 1993; Sarathchandra et al. 1997; Borowik et al. 2017). Varied amounts of microorganisms in different soil samples may be associated with their succession induced by the death of sensitive microorganisms and reproduction of more tolerant ones (Borowik et al. 2017). The number of cultivable microorganisms in the examined Spitsbergen soils was very high (Fig. 2a). The number of oligo- and copiotrophs was similar to the number determined in the rhizosphere of Allium sp. in temperate climate (Winiarczyk et al. 2014). In Allium rhizosphere, a lower number of oligothan copiotrophs was detected, but similar numbers were observed in root free soil. Such results, also in the Spitsbergen soil, may be connected with a small increase in plant biomass and, hence, with a small amount of root exudates. Similar to Kotsou et al. (2004), we obtained high EP indices for both copioand oligotrophs, which indicated high bacterial diversities, and the lowest EP values for fungi (Fig. 3b). The highest values of the $\mathrm{CD}$ index were achieved mainly by fungi, while oligotrophs were characterized by the lowest $C D$ value (Fig. 3c), which indicated that these microbial groups represented the $\mathrm{r}$ and $\mathrm{K}$ strategies, respectively. This indicates that the abundance of fungi was generally low, which corresponded with the higher number of bacteria. Our results partially corresponded with the data presented by Shatlovich et al. (2009).

In polar regions, the variation in the bacterial community structure is based on various factors, e.g. the soil depth or the season of the year (Blaud et al. 2015; Kosek et al. 2018). In our research, it seems that the number and biodiversity of microorganisms is multicausal.
Relationships between soil and microorganisms

The physico-chemical properties of soil do not clearly explain the number of rhizosphere microorganisms, which is in opposition to the data reported by Mapelli et al. (2018). Recent findings show that both copiotrophic and oligotrophic life strategies exhibited by members of many bacterial phyla were consistent with their capacity to degrade carbon. However, they responded positively and negatively to nitrogen amendments (Ho et al. 2017), which is in agreement with our results that the microbiome reacts diversely to environmental agents.

The concentration of the studied heavy metals in the soil and the mean number of microorganisms were subjected to the PCA ordination analysis (Fig. 4c). It evidenced statistical significance of all tested variables, except for the number of fungi and for the $\mathrm{Cr}$ content for the first axis and the $\mathrm{Cr}, \mathrm{Cu}$, and Mn level for the second one. The first axis of the ordination diagram explained $33 \%$, the second ca. $24 \%$, and 4 axes ca. $81 \%$ of the data variation. The first axis was negatively correlated with the number of copio-, oligotrophs, and fungi and there was a strong positive relationship with the $\mathrm{Cu}, \mathrm{Mn}$, and $\mathrm{Fe}$ content. The second axis was strongly positively correlated with the number of microorganisms and negatively correlated with $\mathrm{Zn}$.

In agreement with Grzesiak et al. (2015), in spite of the differences in the content of some elements in the analysed soils, the microbial numbers are comparable, thus the absence of a direct relationship between the content of the studied elements in the soil and the number of microorganisms (Fig. 4c) was confirmed. This suggests that other factors control the microbiome population. The structure of the microbial community was partially dependent on $\mathrm{pH}$, soil water content, and the content of $\mathrm{C}$ and $\mathrm{N}$. Moreover, soil microorganisms play a key role in release of nutrients from minerals, thereby forming a new environment not only for themselves, but also directly for plants (Górniak et al. 2017). The number of culturable microorganisms was very high, which implies that they were considerably involved in the transformation of compounds containing $\mathrm{C}, \mathrm{N}$, and $\mathrm{P}$, as well as in the availability of heavy metals. The microorganisms exhibited great plasticity and adaptability to the adverse Arctic environment. 

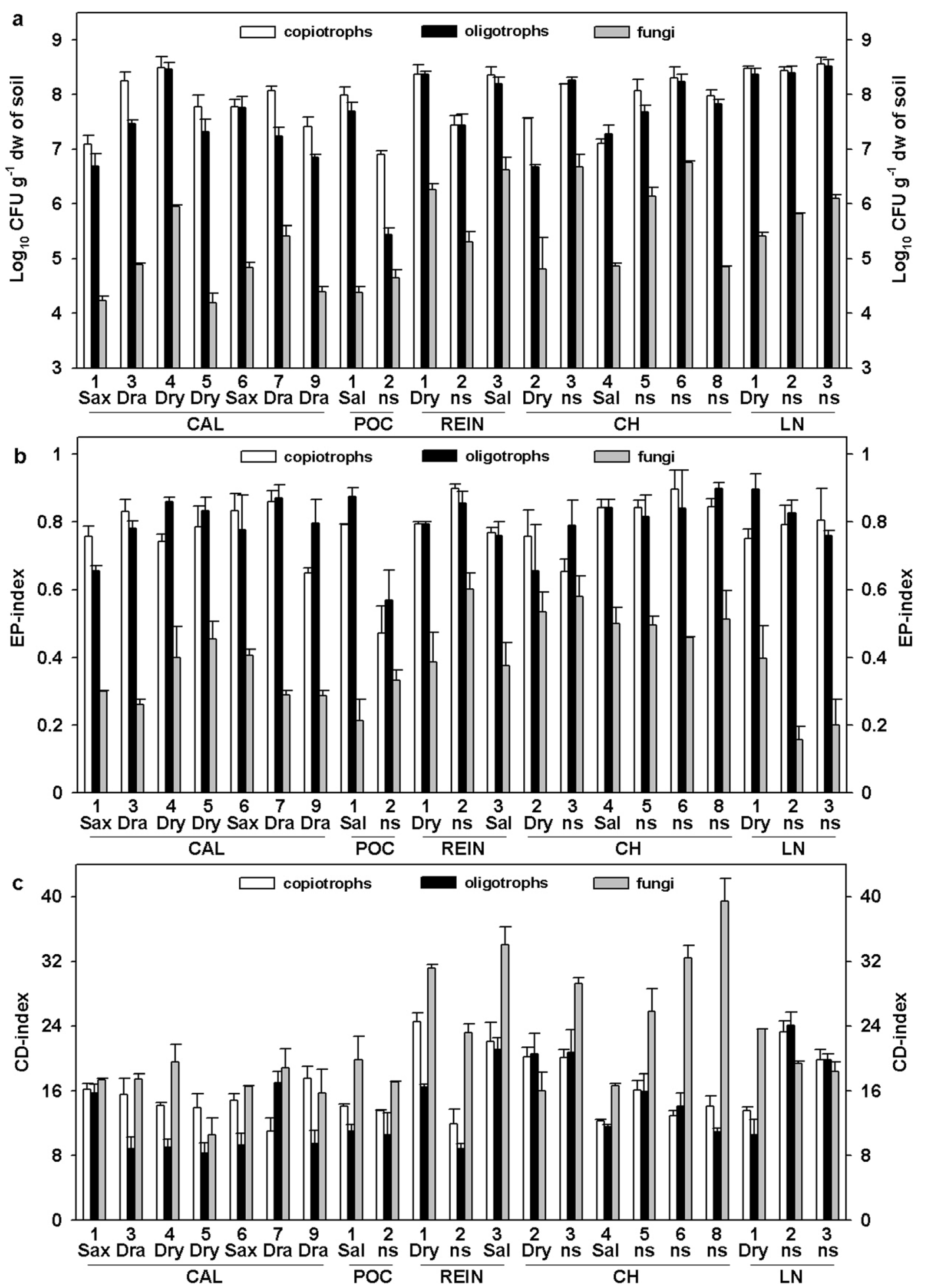

Fig. 3 Microbiological data $\bar{X} \pm \mathrm{SD})$ : (a) number of microorganisms, (b) EP-index, and (c) CD-index. Abbreviations: Dra - Draba corymbosa; Dry - Dryas octopetala; Oxy - Oxyria digyna; Sal -
Salix polaris; Sax - Saxifraga oppositifolia; Sil - Silene uralensis; other abbreviations as in Table 1 


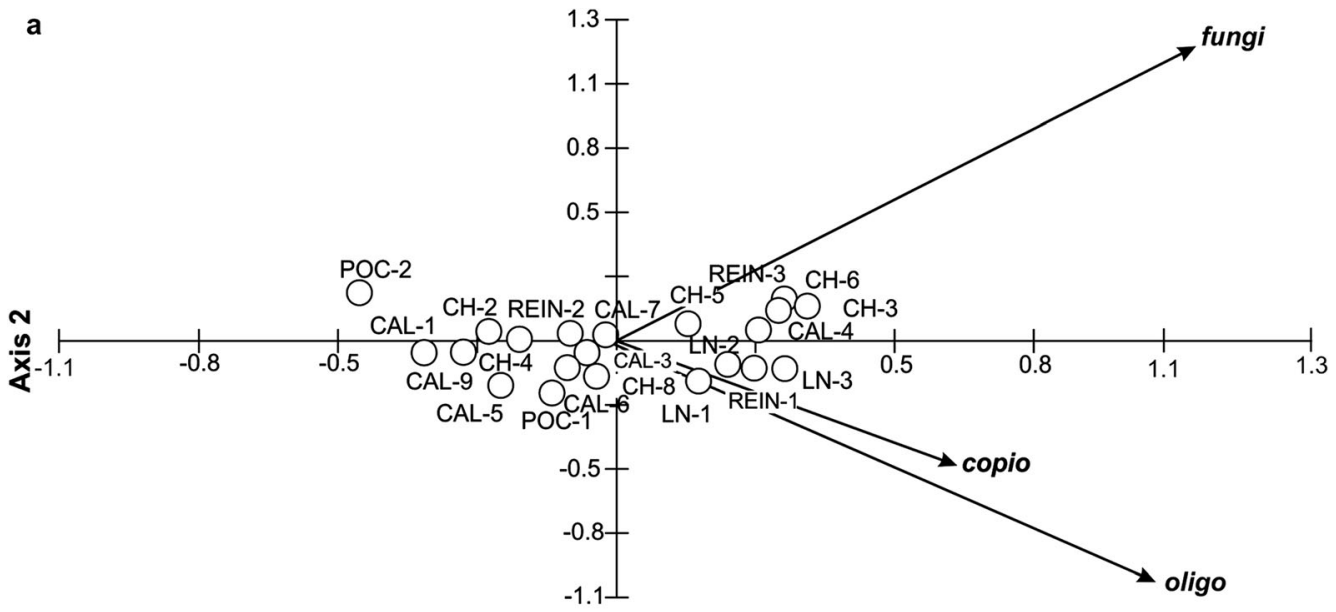

Axis 1

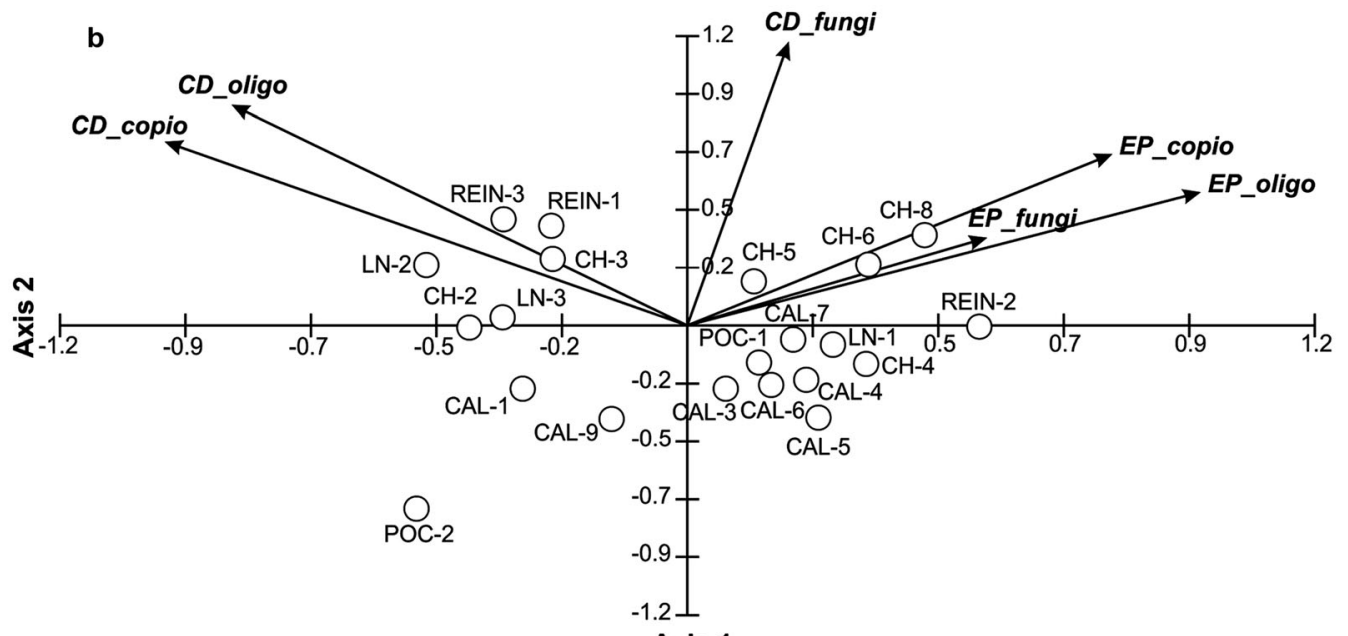

Axis 1

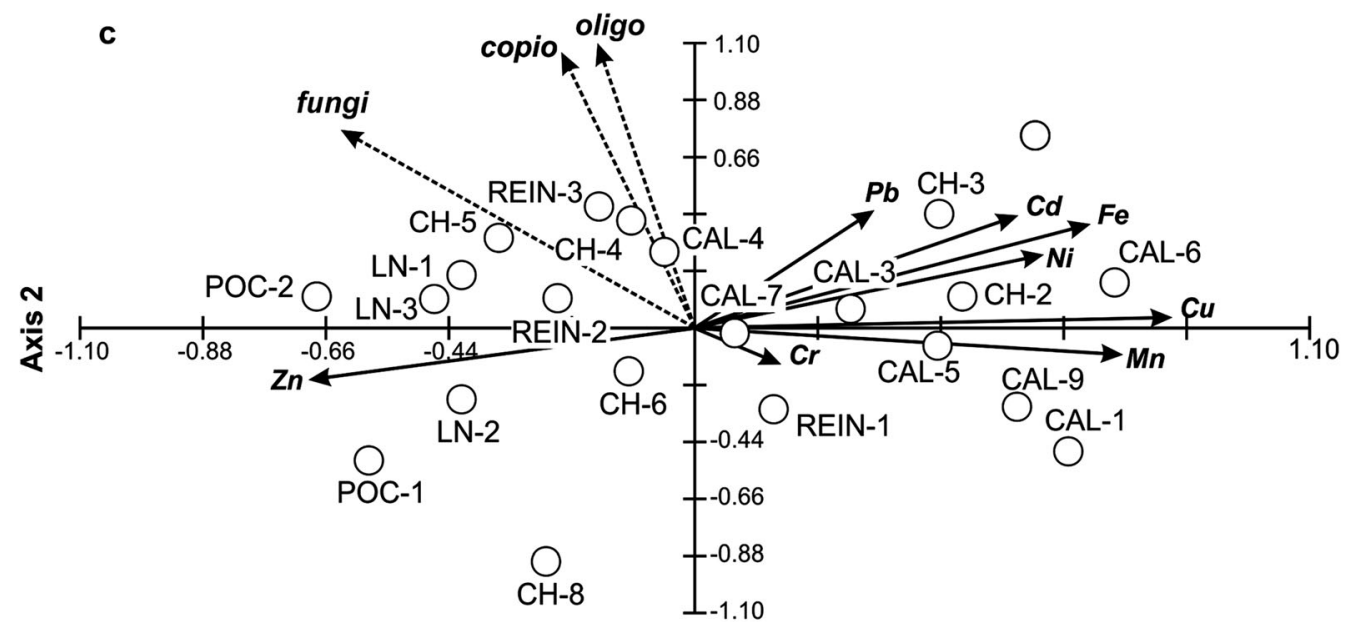

Axis 1 
Fig. 4 Ordination diagram showing the result of the PCA for microorganisms: a the average number of oligo, oligotrophs; copio, copiotophs, and fungi. Eigenvalues: Axis 1-1.29, Axis 214.50. b The EP and CD indices. Axis 1-2.14, Axis 2-1.72. c The relationship between concentration of heavy metals in the soil and the mean number of microorganisms. Axis 1-3.65, Axis 2-2.63. Other abbreviations as in Table 1

Relationships between soil, microorganisms, and plants

Our interdisciplinary experiments matching the different levels of environmental agents (e.g. geomorphology, climate, soil properties, plants, and microorganisms) completed the picture of the multi-dependence in nature. Our results did not confirm a direct relationship between the content of the studied elements in the soil, plants, and the number of microorganisms.

The main mechanism regulating the dynamic equilibrium among the soil parameters, plant species, and microbial numbers and biodiversity can rely on the balance between local substrate availability, microhabitat conditions, and meteorological elements. According to the concept of niche construction, interactions of living organisms modify their physical environment influencing geomorphologic processes and surface structures (Corenblit et al. 2011). Plants and microorganisms can accelerate the production of various clay minerals, thus soils should be treated as expression of biological evolution. Moreover, soil fertility and metal content are associated with plants (Wojtuń et al. 2013). The organisms living in the adverse environment of Spitsbergen have developed specific physiological and/or anatomical adaptations, which improved their resistance and survival possibilities leading to eco-evolutionary (e.g. the structure of local communities) and co-evolutionary changes (e.g. coadjustments between biotic and abiotic factors) (Corenblit et al. 2008, 2011).

Furthermore, with increasing temperature and wetter conditions, microbial and plant communities can significantly change their structure and activity, which may be responsible for an increase in the efflux of gases (Nikrad et al. 2016). Given the multifactorial dependence of living organisms in adverse environmental conditions, the ability of plants and microorganisms to develop unique properties and mechanisms to survive and cope with unfavourable agents seems worth exploring.

\section{Conclusions}

The soil samples varied considerably in $\mathrm{pH}$ - from acid to alkaline, texture - from sand to loamy sand, and C:N ratio - from very low to high. No significant impact of the geochemical properties on the total content of heavy metals in the soil was identified. Heavy metals in soils were locally distributed with a limited influence of the human activity, which was confirmed by only partial $\mathrm{Cd}$ elevation presented as $\mathrm{I}_{\text {geo }}$ and EF. Metals in the plants were distributed depending on the life form, i.e. their content was higher in the woody perennials, such as Salix polaris, Dryas octopetala, and Draba corymbosa than in the herbaceous perennials, but the concentration of the metals was species-dependent. The similar position of $\mathrm{Cd}$ and $\mathrm{Pb}$ in the order of heavy metal accumulation in the soil and plants was confirmed. TF showed that mainly these two metals were transported efficiently from roots to shoots. Very high numbers of culturable microorganisms were determined, regardless of the soil properties and plant species, which indicated that they were involved in the transformation of compounds containing $\mathrm{C}, \mathrm{N}$, and $\mathrm{P}$, and in the availability of heavy metals. The microorganisms and plants colonizing Spitsbergen soils showed great plasticity and adaptability not only to low temperatures, but also to other extreme conditions (e.g. presence of $\mathrm{Cd}$ ), which indicates that they have a high potential to be used in investigations conducted in other extreme conditions.

Acknowledgements This research was partially supported by the Polish National Science Centre, project no. 2013/09/B/ST10/04141 and partially supported by the Polish National Science Centre, project no. 2017/01/X/NZ8/00859.

Open Access This article is distributed under the terms of the Creative Commons Attribution 4.0 International License (http:// creativecommons.org/licenses/by/4.0/), which permits unrestricted use, distribution, and reproduction in any medium, provided you give appropriate credit to the original author(s) and the source, provide a link to the Creative Commons license, and indicate if changes were made.

\section{References}

Agrawal YC, McCave IN, Riley JB (1991) Laser diffraction size analysis. In: Syvitski JPM (ed) Pronciples, methods and application of particle size analysis. Cambridge University Press, New York, pp 119-128 
Alef K (1995) Dehydrogenase activity. In: Alef K, Nannipieri P (eds) Methods in applied soil microbiology and biochemistry. Academic Press, London, pp 228-231

Birkenmajer K (2004) Caledonian basement in NW wedel Jarlsberg land south Bellsund. Spitsbergen Pol Polar Res 25(1):3-26

Blaud A, Phoenix GK, Osborn AM (2015) Variation in bacterial, archaeal and fungal community structure and abundance in high Arctic tundra soil. Polar Biol 38:1009-1024. https://doi. org/10.1007/s00300-015-1661-8

Borowik A, Wyszkowska J, Kucharski J, Baćmaga M, Tomkiel M (2017) Response of microorganisms and enzymes to soil contamination with a mixture of terbuthylazine, mesotrione, and S-metolachlor. Environ Sci Pollut Res 24:1910-1925. https://doi.org/10.1007/s11356-016-7919-z

Borysiak J, Ratyńska H (2004) Stan badań nad szatą roślinną Spitsbergenu ze szczególnym uwzględnieniem rejonów Bellsund, Hornsund i Kaffiøyra. In: Kostrzewski A, Pulina M, Zwoliński Z (eds) Warsztaty glacjologiczne Spitsbergen 2004. Glacjologia, geomorfologia i sedymentacja środowiska polarnego Spitsbergenu. Stowarzyszenie Geomorfologów Polskich, Poznań (in Polish)

Corenblit D, Baas ACW, Bornette G, Darrozes J, Delmotte S, Francis RA, Gurnell AM, Julien F, Naiman RJ, Steiger J (2011) Feedbacks between geomorphology and biota controlling earth surface processes and landforms: a review of foundation concepts and current understandings. Earth Sci Rev 106:307-331. https://doi.org/10.1016/j.earscirev.2011.03.002

Corenblit D, Gurnell AM, Steiger J, Tabacchi E (2008) Reciprocal adjustments between landforms and living organisms: extended geomorphic evolutionary insights. Catena 73:261273. https://doi.org/10.1016/j.catena.2007.11.002

De Leij FAAM, Whipps JM, Lynch JM (1993) The use of colony development for the characterization of bacterial communities in soil and on roots. Microb Ecol 27:81-97. https://doi. org/10.1007/BF00170116

Dragović S, Mihailović N, Gajić B (2008) Heavy metals in soils: distribution, relationship with soil characteristics and radionuclides and multivariate assessment of contamination sources. Chemosphere 72:491-495. https://doi.org/10.1016 /j.chemosphere.2008.02.063

Dziadowiec H, Gonet S, Plichta W (1994) Properties of humic acids of Arctic tundra soils in Spitsbergen. Pol Polar Res 15(1-2):71-81

Egner H, Riehm H, Domingo WR (1960) Untersuchungen veber die chemische bodenanalyse als grundlage fur die bevrteilung des nahrstoffzustandes der boden. II. Chemische extraktionsmetoden zu phosphor - und kaliumbestimmung K. Lantbr Hogsk Annlr 26:199-215 (in German)

Franczak L, Kociuba W, Gajek G (2016) Runoff variability in the Scott River (SW Spitsbergen) in summer seasons 2012-2013 in comparison with the period 1986-2009. QuaGeo 35(3):39-50

Górniak D, Marszałek H, Kwaśniak-Kominek M, Rzepa G, Manecki M (2017) Soil formation and initial microbiological activity on a foreland of an Arctic glacier (SW Svalbard). Appl Soil Ecol 114: 34 44. https://doi.org/10.1016/j.apsoil.2017.02.017

Gulińska J, Rachlewicz G, Szczuciński W, Barałkiewicz D, Kózka M, Bulska E, Burzyk M (2003) Soil contamination in high Arctic areas of human impact, Central Spitsbergen. Svalbard Pol J Environ Stud 12(6):701-707

Grzesiak J, Górniak D, Świątecki A, Aleksandrzak-Piekarczyk T, Szatraj K, Zdanowski MK (2015) Microbial community development on the surface of Hans and Werenskiold glaciers (Svalbard, Arctic): a comparison. Extremophiles 19: 885-897. https://doi.org/10.1007/s00792-015-0764-z

Halbach K, Mikkelsen Ø, Berg T, Steinnes E (2017) The presence of mercury and other trace metals in surface soils in the Norwegian Arctic. Chemosphere 188:567-574. https://doi. org/10.1016/j.chemosphere.2017.09.012

Hao ZL, Wang F, Yang HZ (2013) Baseline values for heavy metals in soils on Ny-Alesund, Spitsbergen Island, Arctic: the extent of anthropogenic pollution. Adv Mater Res 779: 1260-1265. https://doi.org/10.4028/www.scientific. net/AMR.779-780.1260

Ho A, Di Lonardo DP, Bodelier PLE (2017) Revisiting life strategy concepts in environmental microbial ecology. FEMS Microbiol Ecol 93. https://doi.org/10.1093/femsec/fix006

ISO 11466 (1995) International standard. In: Soil qualityextraction of trace elements soluble in aqua regia. Geneve, Switzerland

IUSS Working Group WRB (2015) World Reference Base for soil resources 2014, update 2015. World soil resources reports no. 106. FAO, Rome, Italy

Kleiden A, Mooney HA (2000) A global distribution of biodiversity inferred from climatic constraints: results from a processbased modelling study. Glob Chang Biol 6:507-523. https://doi.org/10.1046/j.1365-2486.2000.00332.x

Klimowicz Z, Melke J, Uziak S, Chodorowski J (2009) Specificity of Arctic tundra soils of Spitsbergen. Pol J Soil Sci 42:97-109

Klimowicz Z, Uziak S (1988) Soil-forming processes and soil properties in Calypsostranda, Spitsbergen. Pol Polar Res 9(1):61-71

Kłos A, Ziembik Z, Rajfur M, Dołhańczuk-Śródka A, Bochenek Z, Bjerke JW, Tømmervik H, Zagajewski B, Ziółkowski D, Jerz D, Zielińska M, Krems P, Godyń P (2017) The origin of heavy metals and radionuclides accumulated in the soil and biota samples collected in Svalbard, near Longyearbyen. Ecol Chem Eng S 24(2):223-238. https://doi.org/10.1515/eces-2017-0015

Kosek K, Kozak K, Kozioł K, Jankowska K, Chmiel S, Polkowska Ż (2018) The interaction between bacterial abundance and selected pollutants concentration levels in an arctic catchment (Southwest Spitsbergen, Svalbard). Sci Total Environ 622-623:913-923. https://doi.org/10.1016/j. scitotenv.2017.11.342

Kotsou M, Mari I, Lasaridi K, Chatzipavlidis I, Balis C, Kyriacou A (2004) The effect of olive oil mill wastewater (OMW) on soil microbial communities and suppressiveness against Rhizoctonia solani. Appl Soil Ecol 26:113-121. https://doi. org/10.1016/j.apsoil.2003.12.001

Kovach WL (1999) MVSP - A Multi-Variate Statistical Package for Windows, ver. 3.1. Kovach Computing Services, Pentraeth, Wales, U.K.

Krajcarová L, Novotný K, Chattová B, Elster J (2016) Elemental analysis of soils and Salix polaris in the town of Pyramiden and its surroundings (Svalbard). Environ Sci Pollut Res 23: 10124-10137. https://doi.org/10.1007/s11356-016-6213-4

Kurek E, Ozimek E, Sobiczewski P, Słomka A, Jaroszuk-Ściseł J (2013) Effect of Pseudomonas luteola on mobilization of phosphorus and growth of young apple trees (Ligol) - pot experiment. Sci Hortic 164:270-276. https://doi.org/10.1016 j.scienta.2013.09.012

Mapelli F, Marasco R, Fusi M, Scaglia B, Tsiamis G, Rolli E, Fodelianakis S, Bourtzis K, Ventura S, Tambone F, Adani F, 
Borin S, Daffonchio D (2018) The stage of soil development modulates rhizosphere effect along a high Arctic desert chronosequence. ISME J 12:1188-1198. https://doi. org/10.1038/s41396-017-0026-4

Martin JP (1950) Use of acid, rose bengaland streptomycin in the plate method for estimating soil fungi. Soil Sci 69(3):215232

Melke J, Uziak S (2006) Heavy metals in soils and vascular plants of the Bellsund area (Spitsbergen). Pol J Soil Sci 39(2):151164

Mędrek K, Gluza A, Siwek K, Zagórski P (2014) The meteorological conditions on the calypsobyen in summer 2014 on the background of multiyear 1986-2011. Probl Klim Polar 24: 37-50 (in Polish)

Muller G (1969) Index of geo-accumulation in sediments of the Rhine River. Geol J 2:108-118

Norwegian Polar Institute (2016) Offline geological map of Svalbard, Geological map of Svalbard (1:250 000). http://svalbardkartet.npolar.no/. Accessed 20 Apr 2018

Nikitina M, Popova L, Korobicina J, Efremova O, Trofimova A, Nakvasina E, Volkov A (2015) Environmental status of the Arctic soils. J Elem 20(3):643-651. https://doi.org/10.5601 /jelem.2014.19.4.743

Nikrad MP, Kerkhof LJ, Haggblom MM (2016) The subzero microbiome: microbial activity in frozen and thawing soils. FEMS Microbiol Ecol 92:1-16. https://doi.org/10.1093 /femsec/fiw081

Nilsen L, Brossard T, Joly D, Elvebakk A (1999) Mapping and analysing arctic vegetation; evaluating a method coupling numerical classification of vegetation data with SPOT satellite data in a probability model. Int J Remote Sens 20:29472977. https://doi.org/10.1080/014311699211552

Ottesen RT (2015) Geochemistry of superficial deposits. In: Dallmann WK (ed) Geoscience atlas of Svalbard. Norwegian polar institute report 148, Tromsø, pp 241-247

Ottesen RT, Bogen J, Finne TE, Andersson M, Dallmann WK, Eggen OA, Jartun M, Lundkvist Q, Pedersen HR, Volden T (2010) Geochemical Atlas of Norway. Part 2: Geochemical Atlas of Spitsbergen - Geochemical Composition of Overbank Sediments. Geological Survey of Norway (NGU), Trondheim, Norway

Sarathchandra SU, Burch G, Cox NR (1997) Growth patterns of bacterial communities in the rhizoplane and rhizosphere of white clover (Trifolium repens L.) and perennial ryegrass (Lolium perenne L.) in long-term pasture. Appl Soil Ecol 6: 293-299. https://doi.org/10.1016/S0929-1393(97)00015-2

Shatlovich AV, Shmakova LA, Mylnikov AP, Gilichinsky PA (2009) Ancient Protozoa isolated from permafrost. In: Margesin R (ed) Permafrost soils. Springer-Verlag, Berlin, Heidelberg

Soil Survey Staff (2006) Keys to soil taxonomy, tenth edition. United States Department of Agricultura. NRCS 1-332

Solheim B, Endal A, Vigstad H (1996) Nitrogen fixation in Arctic vegetation and soils from Svalbard, Norway. Polar Biol 16: 35-40. https://doi.org/10.1007/BF01876827

Szymański W, Siwek J, Waścińska J, Wojtuń B (2016) Texture and geochemistry of surface horizons of Arctic soils from a nonglaciated catchment, SW Spitsbergen. Pol Polar Res 37(3): 361-377. https://doi.org/10.1515/popore-2016-0019

Szymański W, Skiba M, Wojtuń B, Drewnik M (2015) Soil properties, micromorphology, and mineralogy of Cryosols from sorted and unsorted patterned grounds in the Hornsund area, SW Spitsbergen. Geoderma 253-254:1-11. https://doi.org/10.1016/j.geoderma.2015.03.029

Tomlinson DC, Wilson JG, Harris CR, Jeffrey DW (1980) Problems in the assessment of heavy metals in estuaries and the formation pollution index. Helgol Mar Res 33:566-575. https://doi.org/10.1007/BF02414780

Tomova I, Stoilova-Disheva M, Vasileva-Tonkova E (2014) Characterization of heavy metals resistant heterotrophic bacteria from soils in the Windmill Islands region, Wilkes Land, East Antarctica. Pol Polar Res 35(4):93-607. https://doi. org/10.2478/popore-2014-0028

Van Reeuwijk LP (2002) Procedures for soil analysis 6th edition. International soil reference and information Centre (ISRIC), Wageningen

Walker MD, Wahren CH, Hollister RD, Henry GHR, Ahlquist LE, Alatalo JM, Bret-Harte MS, Calef MP, Callaghan TV, Carroll AB, Epstein HE, Jonsdottir IS, Klein JA, Magnusson B, Molau U, Oberbauer SF, Rewa SP, Robinson CH, Shaver GR, Suding KN, Thompson CC, Tolvanen A, Totland O, Turner PL, Tweedie CE, Webber PJ, Wookey PA (2006) Plant community responses to experimental warming across the tundra biome. Proc Natl Acad Sci U S A 103(5):13421346. https://doi.org/10.1073/pnas.0503198103

Williams DE (1949) A rapid manometer method for the determination of carbonate in soils 1. Soil Sci Soc Am Proc 13(C): 127

Winiarczyk K, Skrzypczak K, Jaroszuk-Ściseł J, Bocianowski J (2014) Investigations of the capacity and strength of seed germination in Allium victorialis L. Acta Soc Bot Pol 83(3): 219-228. https://doi.org/10.5586/asbp.2014.021

Wojtuń B, Samecka-Cymerman A, Kolon K, Kempers AJ, Skrzypek G (2013) Metals in some dominant vascular plants, mosses, lichens, algae, and the biological soil crust in various types of terrestrial tundra, SW Spitsbergen, Norway. Polar Biol 36:1799-1809. https://doi.org/10.1007/s00300-0131399-0

Wolińska A, Rekosz-Burlaga H, Goryluk-Salmonowicz A, Błaszczyk M, Stępniewska Z (2015) Bacterial abundance and dehydrogenase activity in selected agricultural soils from Lublin region. Pol J Environ Stud 24(6):2677-2682. https://doi.org/10.15244/pjoes/59323

Zagórski P (2005) NW part of Wedel Jarlsberg Land (Spitsbergen, Svalbard, Norway). In: Pękala K, Aas HF (eds) Orthophotomap 1:25000. UMCS, Norsk Polarinstitutt, Lublin, Poland

Zagórski P (2013) Geomorphological Map of NW Part of Wedel Jarlsberg Land (Spitsbergen, Svalbard). In: Zagórski P, Harasimiuk M, Rodzik J (eds) Geographical Environment of NW Part of Wedel Jarlsberg Land (Spitsbergen, Svalbard). Wydawnictwo UMCS, Lublin, Poland, Appendix 2

Zagórski P, Rodzik J, Strzelecki MC (2013) Coastal Geomorphology In: Zagórski P, Harasimiuk M, Rodzik J (eds), Geographical environment of NW part of Wedel Jarlsberg Land (Spitsbergen, Svalbard), Wydawnictwo UMCS, Lublin, Poland, pp 212-245

Ziółek M, Bartmiński P, Stach A (2017) The influence of seabirds on the concentration of selected heavy metals in organic soil on the Bellsund coast, Western Spitsbergen. Arct Antarct Alp Res 49(4):507-520. https://doi.org/10.1657/AAAR0016-024 